\title{
Identification of Bmi1-interacting proteins as constituents of a multimeric mammalian Polycomb complex
}

\author{
Mark J. Alkema, ${ }^{1}$ Marieke Bronk, ${ }^{1}$ Els Verhoeven, ${ }^{1,2}$ Arie Otte ${ }^{3}$ Laura J. van 't Veer, ${ }^{2}$ Anton \\ Berns, ${ }^{1}$ and Maarten van Lohuizen ${ }^{2,4}$ \\ The Netherlands Cancer Institute ${ }^{1}$ Division of Molecular Genetics and ${ }^{2}$ Molecular Carcinogenesis, 1066 CX Amsterdam, \\ The Netherlands; ${ }^{3}$ E.C. Slater Institute, University of Amsterdam, 1078 TV Amsterdam, The Netherlands
}

The Bmi1 gene has been identified as a mouse Polycomb group (Pc-G) gene implicated in the regulation of Hox gene expression. Here we describe the characterization of a Bmi binding protein Mph1, which shares similarity to Drosophila polyhomeotic. Coimmunoprecipitation experiments indicate that Bmil and Mph1, as well as the Mel18 and M33 proteins described previously, are constituents of a multimeric protein complex in mouse embryos and human cells. A central domain of Bmil interacts with the carboxyl terminus of Mph1, whereas a conserved $\alpha$-helical domain in the Mph1 protein is required for its homodimerization. Transgenic mice overexpressing various mutant Bmi1 proteins demonstrate that the central domain of Bmi1 is required for the induction of anterior transformations of the axial skeleton. Bmi1, M33, and Mph1 show an overlapping speckled distribution in interphase nuclei. These data provide molecular evidence for the existence of a mammalian Polycomb complex.

[Key Words: Bmil; polyhomeotic; Mphl/Rae-28; Polycomb; RING finger; subnuclear localization]

Received July 16, 1996; revised version accepted December 6, 1996.

The vertebrate Hox genes, as well as their Drosophila counterparts, play a key role in the determination of the body plan, as judged from the phenotype of Hox loss- and gain-of-function mutant mice (for review, see Krumlauf 1994). Compared to the fly, relatively little is known about the regulation of Hox gene expression in vertebrates. In Drosophila, the expression pattern of the homeotic genes of the Antennaepedia and Bithorax complexes are initiated early in embryonic development by the gap and pair-rule genes (for review, see Bienz and Müller 1995). These genes are expressed transiently, whereas continuous homeotic gene activity is essential for implementing stable determination of cell fates. Additional factors have been identified that are important for the maintenance of homeotic gene expression patterns throughout subsequent Drosophila development. These maintenance factors fall into two classes: the Polycomb group (Pc-G), which maintains the repressed state in those cells where the homeotic gene was originally inactive [for review, see Paro (1993) and Pirotta (1995)]; and the Trithorax group (trx-G), which sustains the active state in cells where the homeotic gene was originally expressed (for review, see Kennison 1993). At later

${ }^{4}$ Corresponding author.

E-MAIL lohuizen@nki.nl; FAX (31) 205121954. stages of development Pc-G mutants start to express genes of the homeotic clusters outside their normal domains, which results in the transformation of larval segments toward the identity of more posterior ones. Genetic analysis indicates that the Pc-G consists of $\sim 20$ members, 7 of which, namely Polycomb (Pc), polyhomeotic (ph), Posterior sex combs (Psc), Enhancer of zeste [E(z)], Polycomblike (Pcl), extra sex combs (esc), and Sex comb on midleg (Scm), have been characterized at the molecular level [Pirotta (1995) and references therein; Bornemann et al. (1996)]. Genetic and molecular evidence indicates that Pc-G gene products act in large protein complexes. Heterozygous combinations of different Pc-G mutations have a much more severe phenotype (Jürgens 1985) and haplo-insufficient phenotype of some mutants can be rescued by increasing the copy number of another member (Cheng et al. 1994). The Pc protein is localized in large immunologically visible dots in the nucleus (Messmer et al. 1992; Franke et al. 1995) and was found associated in a multimeric complex with at least one other member of the Pc-G, the ph protein (Franke et al. 1992). Furthermore, the $\sim 100$ polytene binding sites for the $\mathrm{Pc}, \mathrm{ph}$, and $\mathrm{Pcl}$ completely coincide and largely overlap with those for Psc (DeCamillis et al. 1992; Franke et al. 1992; Rastelli et al. 1993; Lonie et al. 1994). Pc-G proteins bind to specific regulatory regions, 
so-called Pc-G response elements (PREs), which are necessary for maintaining the repressed state of homeotic genes (Müller and Bienz 1991; Busturia and Bienz 1993; Simon et al. 1993; Chan et al. 1994; Chiang et al. 1995). Little is known, however, about how Pc-G proteins interact molecularly or how they acquire PRE binding site specificity.

There is accumulating evidence that vertebrates use similar mechanisms to maintain Hox gene expression boundaries throughout development. Mammalian homologs have been identified for Trx-G and Pc-G members. The murine M33 protein, which shares distinct regions of homology with the Drosophila Pc protein (Pearce et al. 1992), is able to rescue in part the Pc mutant phenotype in transgenic flies suggesting that Pc-G gene function has been conserved in evolution (Müller et al. 1995). So far, the most striking example of a functional conservation of a murine Pc homolog has been provided by the Bmil proto-oncogene (Haupt et al. 1991; van Lohuizen et al. 1991b) and the closely related Me118 gene (Tagawa et al. 1990). Both gene products share sequence similarity to the Drosophila Psc protein and its relative $\mathrm{Su}(z) 2$ (Brunk et al. 1991; van Lohuizen et al. 1991a). By analogy to Pc-G loss-of-function mutants, Bmil and Mel18 null mutant mice display posterior transformation of the axial skeleton which correlates with an anterior shift of several Hox gene expression boundaries (van der Lugt et al. 1994; 1996; Akasaka et al. 1996). Moreover, transgenic mice that overexpress the $B m i 1$ gene show anterior transformation of the axial skeleton in a Bmil dosage-dependent manner accompanied with a caudal shift of the anterior expression boundary of at least the Hoxc-5 and Hoxc-8 genes (Alkema et al. 1995; van der Lugt et al. 1996). The bidirectional transformations of the axial skeleton of mice haplodeficient for the Mll gene, which shares similarity to the Drosophila trx gene, indicates that TrxG function is conserved in evolution as well (Yu et al. 1995).

To gain further insight into the mechanisms of vertebrate homeotic gene silencing we have identified Bmil binding proteins. In this report we describe the identification of the Mph1 gene, the product of which shares sequence homology with the Drosophila ph protein. We provide evidence that the Mph-1 protein forms homodimers and can directly interact with the Bmil and Mel18 proteins. Coimmunoprecipitation experiments strongly suggest that Bmil, Mel18, Mph1, and M33 are constituents of a multimeric protein complex. We have mapped the Bmil-Mphl interaction domains and correlate this with the phenotype of transgenic mice that overexpress mutant forms of the Bmil gene. Confocal microscopy analysis demonstrated the colocalization of Bmil, Mphl and M33 in multiple subnuclear speckles in interphase nuclei. Our results provide molecular evidence for the existence of a mammalian Pc complex.

\section{Results}

\section{Identification of Bmi1-interacting proteins}

We used the Bmil protein as bait in a yeast two-hybrid screen with a 14.5-day mouse embryo cDNA library
(Chien et al. 1991; Chevray and Nathans 1992). DNA sequence analysis showed that four cDNA library plasmids, recovered from independent positive colonies, all contained the same 2009-bp insert encoding a 600 amino-acid protein. An independent screen of the same two-hybrid library using Mel18 as bait resulted in three positive clones, two of which were identical to the cDNA recovered from the Bmil two-hybrid screen. The third cDNA corresponded to the same gene but contained a shorter 1081-bp insert.

\section{Mph1 is structurally related to the Drosophila ph protein}

Several overlapping cDNA clones from a 16.5-day mouse embryo cDNA library combined with 5 ' RACE products gave a full-length cDNA clone that contained a single long open reading frame (ORF) encoding a 1012-aminoacid protein. The predicted protein sequence showed significant homology to the Drosophila Pc-G family member, polyhomeotic (Deatrick et al. 1991; DeCamillis et al. 1992) (Fig. 1). We therefore named the gene Mph1 (mouse ph). Apart from the length of the $3^{\prime}$ untranslated region the $M p h 1$ cDNA is virtually identical to the Rae28 cDNA that was recently identified as a retinoic acid (RA)-inducible cDNA from F9 embryonal carcinoma cells (Nomura et al. 1994). Some RACE-PCR products were derived from a Mph1 cDNA having a 21 - or $156-\mathrm{bp}$ deletion that would lead to a Mph1 protein lacking amino acid residues $153-159$ or 153-204, respectively. The latter deletion was also reported for some of the Rae-28 cDNA clones (Nomura et al. 1994) and may arise from alternative splicing. We refer to this gene as $M p h 1 /$ Rae-28. Although the overall identity of the Mphl/Rae28 protein to the ph protein was only $30.7 \%$, the $\mathrm{Mphl} /$ Rae-28 and ph protein shared significant similarity at the carboxy-terminal region. A 31-amino-acid homology domain, present in the carboxy-terminal half of the proteins, shows $65 \%$ identity. Another homology domain, comprising a 66-amino-acid stretch at the extreme carboxyl terminus, showed $62 \%$ identity (Fig. 1B). This domain shares weak similarity to a 62- to 67-residue domain present in a diverse set of other proteins, including members of the Ets family of transcription factors (Wasylyk et al. 1993) and a set of cytoplasmic proteins, four of which are involved in sexual differentiation in yeast (Ponting 1995) (Fig. 2). Secondary structure predictions and threading algorithms suggested that the domain has a largely $\alpha$-helical structure comprised of closely packed helices that are connected with short loops. We refer to this domain as the SEP domain (yeast sterility-, Ets related-, PcG proteins). Although the overall homology between the different domains was rather low, the conserved spacing of hydrophobic residues and the conserved $\alpha$-helical-predicted structure suggests a common function. The SEP domain of the ph proteins is most closely related to the carboxy-terminal region of two other recently identified Drosophila gene products. The first, lethal $(3 /$ malignant brain tumor $[1(3) \mathrm{mbt}]$ is the product of a Drosophila tumor suppressor gene (Wismar 


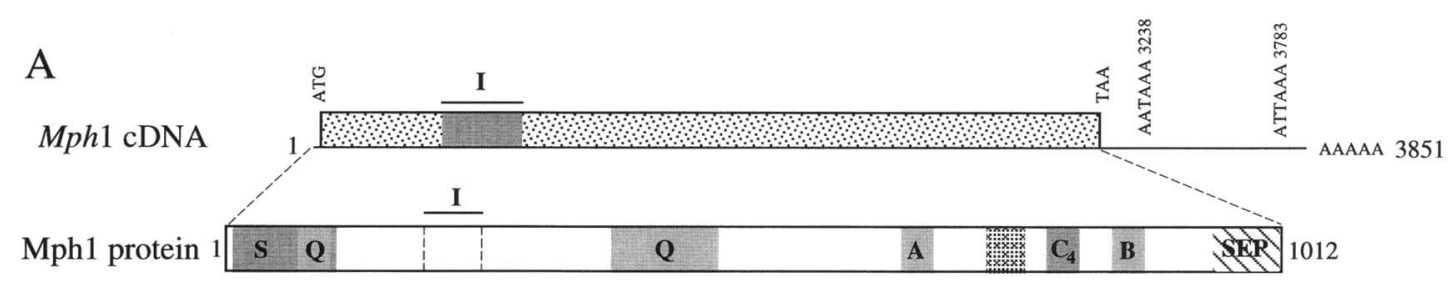

B

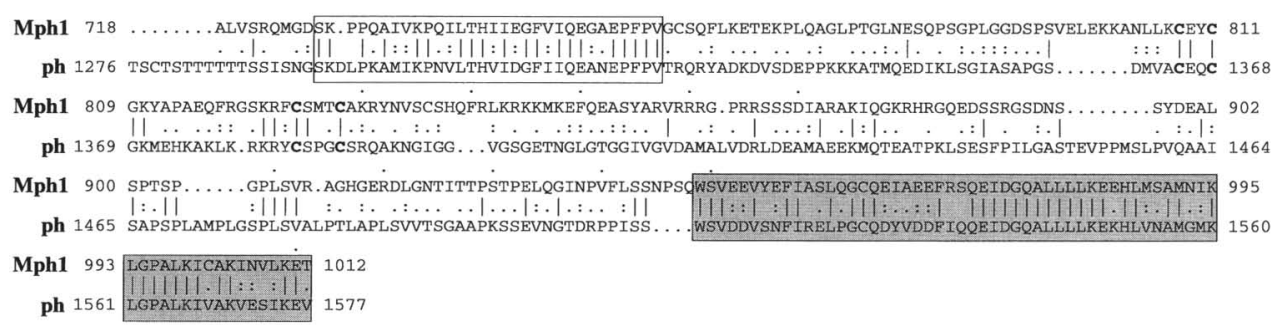

Figure 1. Schematic representation of the $M p h 1$ cDNA and Mphl protein. (A) The complete cDNA clone of Mph1. The Mph1 protein-encoding domain is represented by a stippled bar. The two polyadenylation sites are indicated. The dark-shaded region indicates the part of the cDNA that is missing in some of the 5' RACE PCR products (see text). The 1012-amino-acid protein is represented schematically. The glutamine-rich regions are represented by light shaded boxes $(\mathrm{Q})$. An acidic (A) and basic (B) and a serine-rich (S) region of the $\mathrm{Mphl}$ protein are indicated. The conserved putative $\mathrm{Zn}$ finger $\left(\mathrm{C}_{4}\right)$ and the ph homology domains are represented by dark-shaded boxes. The SEP domain at the extreme carboxyl terminus has a predicted $\alpha$-helical structure and is conserved in a diverse set of eukaryotic proteins. $(B)$ Alignment of the carboxy-terminal half of the Mph1 and ph protein. The first homology domain and the conserved SEP domain are boxed. The conserved cysteines are in boldface type.

et al. 1995). Interestingly, the second protein, Scm, is another member of the Pc-G (Bornemann et al. 1996). The $\mathrm{ph}, \mathrm{Scm}$, and $\mathrm{l}(3) \mathrm{mbt}$ proteins also contain a potential zinc finger of the $\mathrm{C}_{2}-\mathrm{C}_{2}$ type. The conserved structural motifs and similar size suggest that the Mph1/Rae28 protein is a mouse homolog of the Drosophila ph protein.

Using a $M p h 1 /$ Rae-28 cDNA fragment as a probe, a 3.5- and 4-kb transcript were detected on Northern blots
(Fig. 3); their presence correlates with the two consensus polyadenylation signals present in the Mph1/Rae-28 cDNA (Fig. 1). Mph1/Rae-28 is already detected from day 10.5 of gestation (Fig. 3A). Most likely, it is already expressed at earlier stages of development, as transcripts were detected in mouse embryonic stem cells /data not shown). The level of Mph1/Rae-28 expression gradually declined after day 13.5, as is also seen for the M33 gene (Pearce et al. 1992). In adult tissues $M p h 1 /$ Rae-28 was
Figure 2. Alignment of the conserved SEP domains. The SEP domain sequences were aligned with the ClustalW program (Thompson et al. 1994). Alignment of the SEP domains indicates that they can be subdivided into three groups constituting the three Pc-G proteins together with $1(3) \mathrm{mbt}$ (top), a diverse group (middle) including several cytoplasmic proteins (Ponting 1995), and a third group (bottom) consisting of members of the Ets family of transcription factors (Wasylyk et al. 1993) byr2, ste4, and STE50 are involved in sexual differentiation in yeast. splA is a tyrosine kinase protein essential for spore differentiation in Dictyostelium. The DIKI protein is a diacylglycerol kinase isozym.

For the other proteins of the middle group no clear functions have been identified. Amino acid residues that match the consensus sequence are shaded. Residue limits are represented. Secondary structure prediction, using the PHD program (Rost and Sander 1994) showed that the domain constitutes a largely $\alpha$-helical structure. Although two helices were identified at the amino and carboxyl termini of the domain (helix I and III), it is unclear whether the middle part constitutes a single helix or whether it folds into two separate helices (helix IIa and b) connected by a turn-forming glycine. Threading algorithms (Rost 1996) gave positive scores for proteins containing three to five helical bundles. 
A

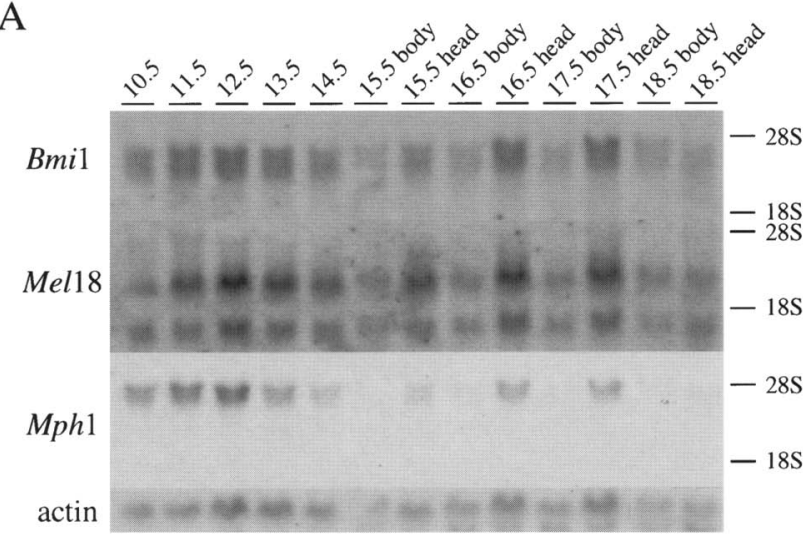

B

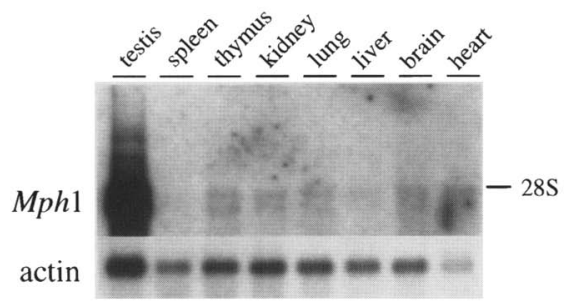

Figure 3. Expression pattern of $M p h 1 /$ Rae-28 (A) Expression of Mph1/Rae-28, Bmil, and Mel18 during embryogenesis. Total RNA $(10 \mu \mathrm{g})$ from total embryos, embryonic head, or body spanning the last 10 days of embryonic development were separated on agarose gels, transferred to nitrocellulose, and subsequently probed with a Bmi1, Mel18, and Mph1/Rae-28 cDNA probe. $(B)$ Expression pattern of $M p h 1 / R a e-28$ in adult tissues. Northern blots containing $5 \mu \mathrm{g}$ of Poly $(\mathrm{A})^{+}$RNA were hybridized with a Mph1/Rae-28 probe. Two Mph1/Rae-28 transcripts of $\sim 3.5$ and $4 \mathrm{~kb}$ were clearly detected in testis after overnight exposure; transcripts in the other tissues were visible after 4 days of exposure. The Northern blots were hybridized with an actin probe to check for the amount of loaded RNA. The $28 \mathrm{~S}$ and $18 \mathrm{~S}$ ribosomal bands are indicated as size markers.

highly expressed in testis, whereas low-expression levels were found in all other tissues analyzed (Fig. 3B). Using an interspecific mouse backcross panel the Mph1/Rae28 gene was mapped to mouse chromosome $6.3 \mathrm{cM}$ distal to the Raf1 proto-oncogene (N.G. Copeland, pers. comm.).

\section{Bmi1 and Mel18 bind to the Mph1/Rae-28 protein in vivo}

To obtain evidence for the association of the Bmil and Mel18 proteins with the Mphl/Rae-28 protein in vivo, antisera were raised against purified glutathione $S$-transferase (GST)-Bmil, GST-Mphl/Rae-28, and MalcMel18 fusion proteins. We could specifically immunoprecipitate the in vitro-transcribed and -translated Bmi1, Mel18, and Mph1/Rae-28 with their cognate antisera. Because the Mph1/Rae-28 gene is highly expressed in 12.5- to 13.5-day embryos, total embryo protein extracts of these developmental stages were used in coimmunoprecipitation experiments. The two polyclonal antisera raised against nonoverlapping parts of the Mph-1/Rae-28 protein detected a 120 - and $130-\mathrm{kD}$ protein doublet on Western blots containing total embryo extracts (Fig. 4A). The observed mobilities of these proteins are larger than the predicted $105 \mathrm{kD}$. This could be attributable to an aberrant mobility on SDS-PAGE as has been observed for other proteins including Bmil (van Lohuizen et al. 1991b). Alternatively, the doublet could represent different post-translationally modified forms of the Mphl/ Rae-28 protein or reflect the different spliced isoforms of the Mph1/Rae-28 gene. Immunoprecipitation with the Mph-MN serum followed by probing the Western blot with the Mph-SM serum revealed two bands characteristic of the Mph $1 /$ Rae-28 protein (Fig. 4A). The same two bands were also seen when protein extracts are precipitated with polyclonal Bmil or Mel18 sera (Fig. 4B). The Mph1/Rae-28 protein was not coprecipitated when the immunoprecipitation was performed with normal rabbit serum, a polyclonal antiserum against the unrelated Pim1 or E2F5 proteins. In addition, when Bmil polyclonal serum was used for immunoprecipitations in Bmi1 -/-embryo protein extracts the Mphl/Rae-28-specific bands were not seen (Fig. 4B) demonstrating that the coprecipitation is not attributable to the formation of aspecific protein aggregates in the embryo extracts.

The polyclonal and monoclonal antibodies against Bmil detected three closely migrating proteins of 45-48 $\mathrm{kD}$ (van Lohuizen et al. 1991b) in total embryo protein extracts (Fig. 4C). The 45- to $48-\mathrm{kD}$ bands were specific for the Bmil protein, as they are not visible in a protein extract from a Bmi1 -/- embryo. The different Bmil protein species were also observed when in vitro-translated ${ }^{35} \mathrm{~S}$-labeled Bmil protein is made (van Lohuizen et al. 1991b). The two highest bands most likely represent phosphorylated isoforms of the Bmil protein, as these isoforms were reduced to the single fastest migrating isoform when in vitro-translated Bmil was treated with calf intestine phosphatase prior to SDS-PAGE (data not shown). The strong band around $55 \mathrm{kD}$ is the result of binding of the second antibody to the mouse immunoglobulin heavy chains present in a 13.5-day embryo protein extract. To further substantiate the specificity of the interaction of Bmil with Mph1/Rae-28 we performed the reciprocal experiment. As shown in Figure $4 \mathrm{C}$ the Bmil protein was coimmunoprecipitated using the polyclonal Mph-SM antibodies.

\section{M33, Mph1/Rae-28, and Bmi1 are present in a multiprotein complex}

We determined whether the murine Pc homolog M33 interacts with the Bmil and Mph1/Rae-28 proteins in embryo extracts. As is shown in Figure $5 \mathrm{~A}$, a polyclonal antiserum raised against M33 specifically coimmunoprecipitates both $\mathrm{Mph} 1 / \mathrm{Rae}-28$ and Bmi-1 from day-12.5 mouse embryo protein extracts. Similarly, we could coimmunoprecipitate human Bmil from human U-2 osteosarcoma (U2-OS) cell extracts (Fig. 5B). The affinity-purified M33 antiserum recognizes a $74-\mathrm{kD}$ protein on Western blots with total extracts from human U2-OS 
A

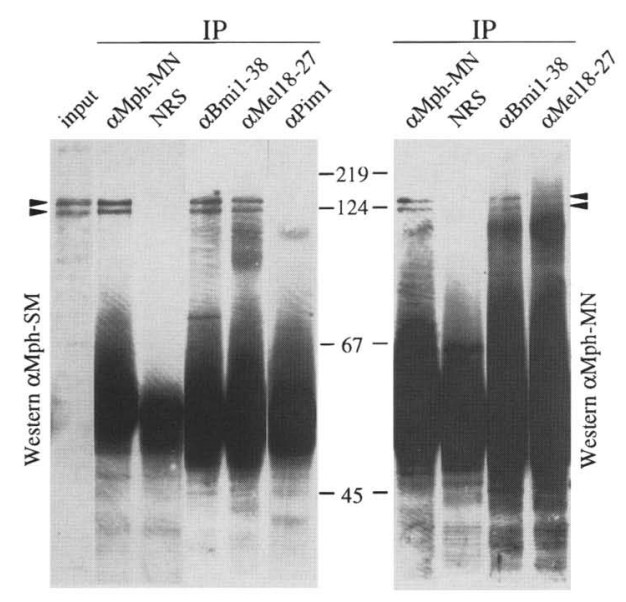

B

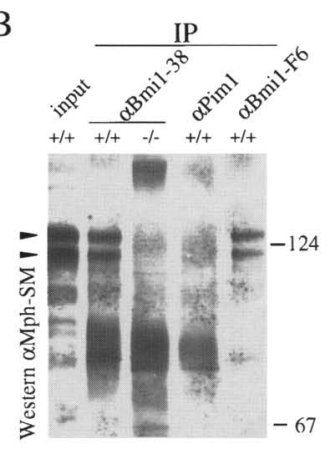

C

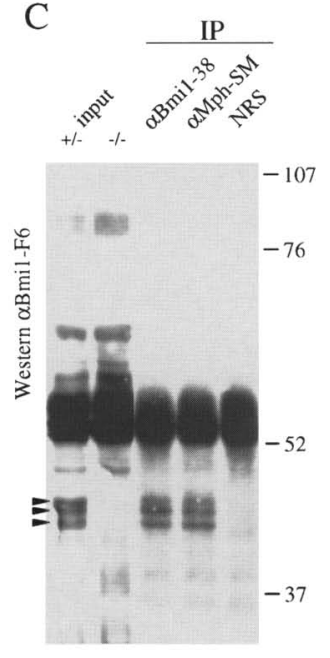

cells, and the specificity of the antiserum was further demonstrated by its abitily to recognize and immunoprecipitate specifically an HA-epitope-tagged M33 expressed in transfected COS cells (data not shown).

In a reciprocal experiment, Bmil-F6 antiserum could not coprecipitate M33 from protein extracts (data not shown). It is possible that the Bmil-F6 antibody interferes with M33 binding or, alternatively, that the interaction between the two proteins is indirect, leading more easily to disruption of the complex during the immunoprecipitations. We favor the latter possibility as we have been unable to demonstrate a direct interaction between the two proteins in a yeast two-hybrid experiment and in COS cell cotransfection experiments (data not shown). Our results demonstrate that M33 is present with Bmil and $\mathrm{Mph} 1 / \mathrm{Rae}-28$ in a multiprotein complex and suggest that the interaction between Bmil and M33 is indirect.

\section{Bmi1, Mph1/Rae-28, and M33 colocalize to subnuclear domains in interphase nuclei}

Further support for the in vivo interaction of Bmil, Mphl/Rae-28, and M33 came from the intracellular lo-

Figure 4. In vivo interaction of $\mathrm{Mph} 1 / \mathrm{Rae}-28$ and Bmil. Immunoprecipitations of embryonic protein extracts with the indicated antibodies were performed under moderate salt conditions, separated on a $9 \%$ SDS-polyacrylamide gels, blotted to nitrocellulose filters, probed with different antibodies, and detected by ECL. The input lane contains $40 \mu \mathrm{g}$ of total 12.5 -day embryo extract. The immunoprecipitations of $250 \mu \mathrm{l}$ of embryo extract were performed with the indicated antibodies. The positions of the molecular mass markers (in $\mathrm{kD}$ ) are indicated. $(A)$ (Left) Western blot probed with the Mph-SM antiserum. Two bands were recognized by the $\mathrm{Mph} 1$ antiserum (indicated with arrowheads). Mphl/Rae-28 is specifically precipitated with the Mph1, Bmil, and Mel18 but not with the Piml or normal rabbit serum (NRS). The heavy smear around $55 \mathrm{kD}$ is the result of cross-reactivity with the heavy chains of the primary antibodies. (Right) The two Mphl/Rae-28 bands were also detected on a Western blot probed with Mph-MN serum, raised against a different part of the Mph1/Rae-28 protein. (B) Control experiment (long exposure) showing that $\mathrm{Mph} 1 / \mathrm{Rae}-28$ was not coprecipitated with the Bmil polyclonal antiserum in Bmil nullizygous embryo extracts $(-/-)$. Mph $1 /$ Rae-28 was also coprecipitated with the Bmil-F6 monoclonal antibody. (C) Western blot probed with Bmil-F6 monoclonal antibody. The three Bmil-specific bands around $45 \mathrm{kD}$ (indicated with arrowheads) were detected in Bmil heterozygous $(+/-)$ embryo protein extracts but are absent in Bmi1 nullizygous embryo extracts $(-/-)$. Bmil is coprecipitated with the Mph1/Rae-28 serum but not with the NRS. The heavy band around $55 \mathrm{kD}$ is the result of cross-reactivity with the heavy chains of the antibodies present in 12.5-day protein extracts.

calization of the endogenous Bmil and Mph1/Rae- 28 proteins in the U2-OS cell line, by indirect immunofluorescence. The Bmil, Mphl/Rae-28, and M33 antisera specifically detected their closely related human homologs (Alkema et al. 1993; A. Otte, pers. comm.), which are expressed at high levels in U2 OS cells (Fig. 5B; data not shown). Specific staining was found in the nucleus with no staining in the cytoplasm (Fig. 6A-G). All three proteins were excluded from the nucleolus and show a speckled distribution throughout the nucleoplasm. A similar Bmil staining pattern was observed in the human erythroid leukemia cell line, K562. Although a speckled Bmil distribution was observed in the nuclei of other cell lines, the size and distribution varied and may correlate with expression levels. For instance, overexpression of Bmil in NIH-3T3 cells, which have a very low endogenous Bmil expression level, led to an increase in size of nuclear speckles (data not shown). Immunofluorescence with the Bmil antibody gave weaker staining in mitotic cells (Fig. 6A). During anaphase no Bmil staining was observed, whereas the Bmil signal reappeared upon chromosome decondensation in late telophase indicating that the large Bmi-1 containing complexes reassemble after mitosis. However, the absence of Bmil staining could reflect the inaccessibility of Bmil for the antibody because of the compact nature of the chromatin at this stage (Messmer et al. 1992). Doublelabeling experiments showed that the staining patterns for the Mph1/Rae-28, Bmil, and M33 proteins completely overlap in interphase nuclei, supporting the in- 


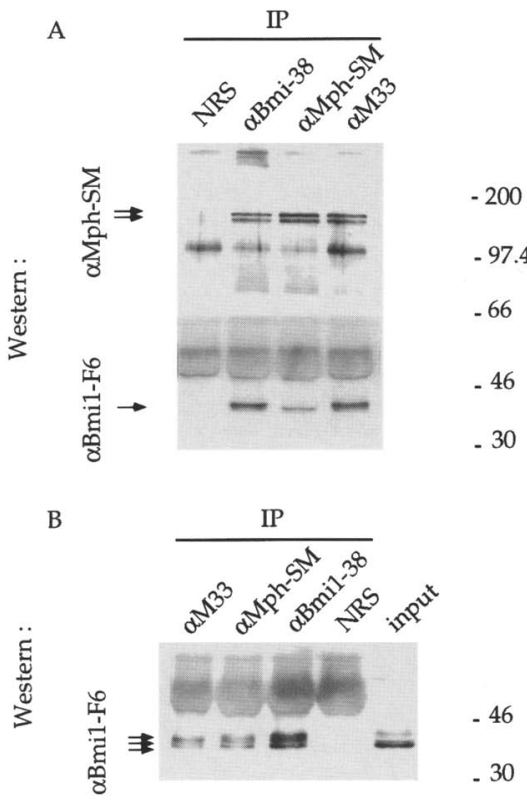

Figure 5. In vivo interaction of $\mathrm{M} 33$ with $\mathrm{Mph} 1 / \mathrm{Rae}-28$ and Bmil. Immunoprecipitations of embryonic protein extracts or human U2-OS cell extracts with the indicated antibodies were performed as described in Fig. 4. The positions of the molecular mass markers (in $\mathrm{kD}$ ) are indicated. $(A)$ The Bmil and $\mathrm{Mphl} /$ Rae- 28 proteins are coprecipitated with the M33 protein. The Bmil- and Mphl/Rae-28-specific bands are indicated with arrowheads. Immunoprecipitations with the Mph-SM and Bmil38 antisera were taken along as positive controls. (B) Bmil is coprecipitated with M33 from human U2-OS cell extracts. The Bmil-and Mph1/Rae-28-specific bands were absent when precipitations were performed with NRS as a negative control.

teraction between these proteins in a multiprotein complex (Fig. 6C,F).

The subnuclear colocalization of the Mphl/Rae- 28 and Bmil proteins is reminiscent of the speckled distribution of the PML oncoprotein, which is involved in acute promyelocytic leukemia (Dyck et al. 1994; Weis et al. 1994). Like Bmil and Mel18, the PML protein contains a RING finger domain that is important for its localization to specific nuclear domains, so-called PML oncogenic domains (PODs). To determine whether Bmil, Mph1/Rae-28, and PML are constituents of the same subnuclear structure we performed a double-labeling experiment with the PML monocional 5E10 (Fig. 6H) and the Mph1/Rae-28 antiserum. Although the PML antibodies recognize similar subnuclear structures they did not colocalize with the ones that contain the Bmil and Mph1/Rae-28 protein (Fig. 6I). Other well-characterized subnuclear domains contain coilin and factors involved in pre-mRNA splicing (Fig. 6K) (Fu and Maniatis 1990). As is demonstrated in Figure 6L, Mph1/Rae-28 also does not colocalize with splicing factors.

\section{Localization of Bmi1 to subnuclear domains depends on an intact RING finger}

Because of the demonstrated importance of the RING finger domain for localization of the PML protein to POD domains (Kastner et al. 1992; Borden et al 1995), we asked whether mutations in the Bmil RING finger would affect its subnuclear distribution. Hereto we transiently transfected HA-epitope-tagged Bmil constructs in which two central cysteines of the RING finger domain were mutated to phenylalanine (Bmil $\Delta \mathrm{Zn}$ ), or HAepitope wild-type Bmil as a control into U2-OS cells. Whereas wild type HA-Bmil colocalizes with Mphl/ Rae-28 in the subnuclear domains (Fig. 7D,E), HA$\mathrm{Bmil} \Delta \mathrm{Zn}$ is diffusely expressed throughout the nucleoplasm in most cells, with some cells displaying enhanced staining of the mutant protein in large subnuclear regions (Fig. 7A,B). These results indicate that as reported for PML, the RING finger is important for subnuclear localization of Bmil, and demonstrate that overexpression of mutant or wild-type Bmil proteins does not detectably alter the subnuclear distribution of endogenous Mphl/Rae-28.

A central domain of Bmi1 interacts with the carboxyl terminus of Mph1/Rae-28

We identified the Bmil-Mph1/Rae-28 interaction domains by the yeast two-hybrid system. As shown in Figure 8, the Gal4-DNA-binding domain (DBD)-Bmil protein containing amino acid 59-227 was the smallest fusion protein that is still able to interact with the Mph1/ Rae- 28 protein. This portion of the Bmil protein harbors a putative helix-turn-helix-turn-helix-turn (HTHTHT) motif that is conserved in the Drosophila Psc protein. Removal of either the carboxy-terminal proline/serinerich region (amino acid 228-324) or the amino-terminal end of the Bmil protein that harbors the RING finger domain did not affect the interaction with the Mphl/ Rae-28 protein. The shortest Mph1/Rae-28 clone recovered from the Bmil/Mell8 two-hybrid screen encoded the carboxy-terminal end of the Mphl/Rae-28 protein starting at amino residue 720 . This portion of the Mphl/ Rae- 28 protein contained the first homology domain, the zinc finger motif, as well as the SEP domain. Deletion of the first Mph1/Rae-28 homology domain no longer gave rise to $\beta$-galactosidase-expressing yeast colonies, suggesting that this domain is essential for the interaction with Bmil. Also deletion of the extreme carboxy-terminal 10 amino acids, which are part of the conserved SEP domain, abrogated Bmil binding. These results indicate that the conserved carboxyl terminus of the Mph1/Rae28 protein is sufficient for the interaction with Bmil and Mel18.

\section{Mph1/Rae-28 forms homodimers}

The two-hybrid embryo cDNA library was also screened with the carboxy-terminal portion of $\mathrm{Mph} 1 / \mathrm{Rae}-28$ (amino acid 413-1012) as bait. Analysis of 10 positive colonies revealed that 6 contained Mph1/Rae-28 cDNA inserts. Four of these clones were identified previously in the two-hybrid screen using Bmil and Mell 8 as bait. The 

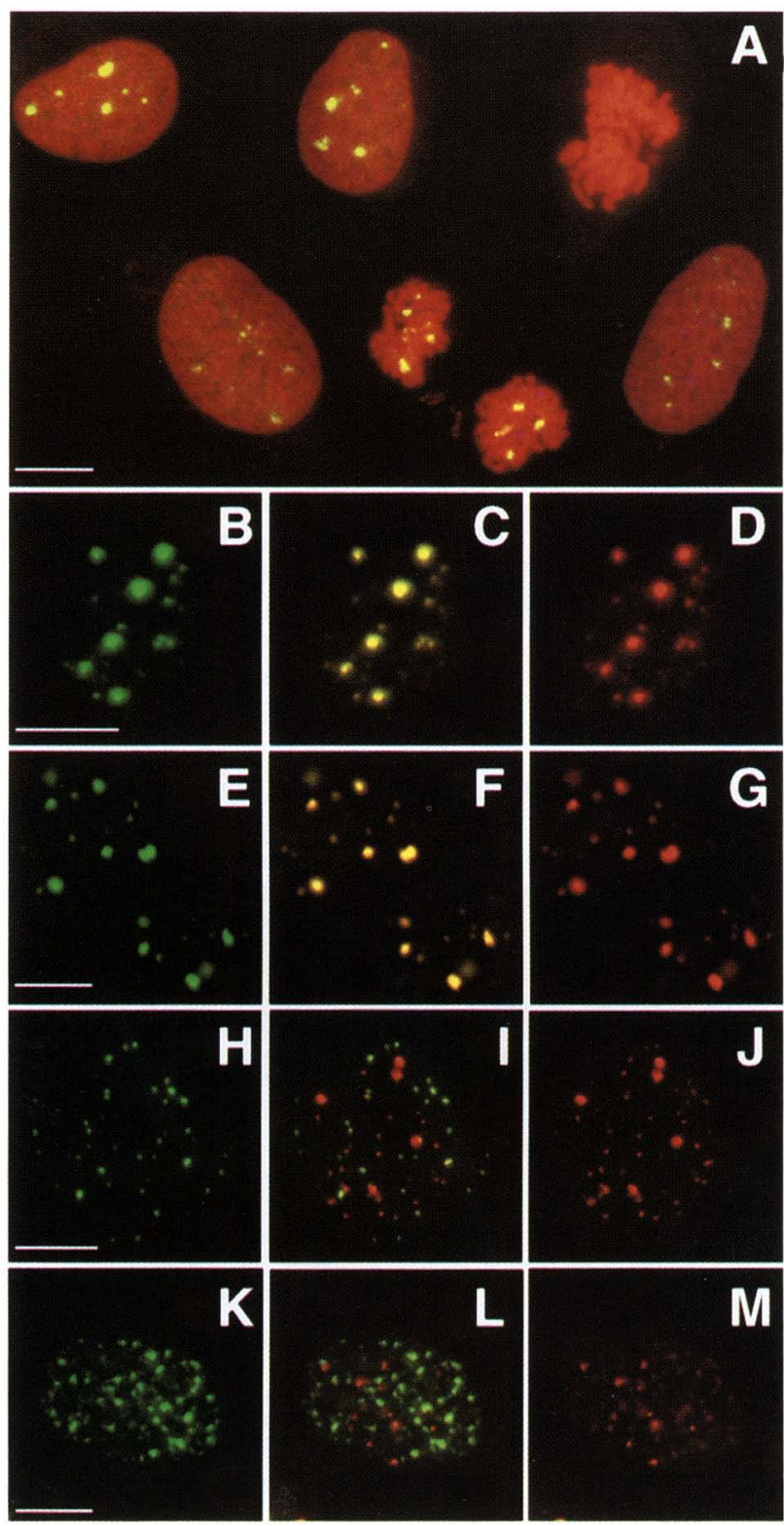

two remaining clones appeared to be identical and contained an insert that encoded the carboxy-terminal part of the Mph1/Rae-28 protein starting at amino acid 847 . This part of the protein starts carboxy-terminal of the zinc finger motif and still contains the SEP domain, which is conserved between the fly and mouse ph proteins. Deletion of the last 10 amino acids of this domain prevented Mph1/Rae-28 dimerization in a two-hybrid assay (Fig. 8A). These results demonstrate that this SEPcontaining carboxy-terminal domain of the Mphl/Rae28 protein is essential and most likely sufficient for dimerization. Bmil or Mel18 cDNA-containing plasmids were not found in this screen. This could be a result of an unfavorable conformation of the Gal4TAD-Bmil/ Mel18 fusion protein, as direct testing of a two-hybrid interaction of a Gal4-DBD-Mphl/Rae-28 with Gal4
Figure 6. Colocalization of endogenous Bmil, Mph1/Rae-28, and M33 proteins in U2-OS cells in distinct subnuclear domains. (A) Subnuclear distribution of Bmil at different cell cycle stages. Indirect immunoflourescence (see Material and Methods) was detected by confocal laser scanning microscopy. The Bmil mAb F6 signal appears in yellow, and nuclear DNA is stained with propidium iodine (red). Bmil staining was absent in mitotic cells (cell in right upper corner) and reappeared in late telophase (two middle cells at the bottom). $(B-D)$ Double-labeling experiment using the Bmil mAb F6 ( $B$, green) and purified polyclonal Mph-SM serum ( $D$, red). The merge of both pictures (C) shows that the Bmil and Mph1/Rae-28 are distributed in a completely overlapping pattern in interphase nuclei. $(E-G)$ Double labelling with Bmil $\mathrm{mAb} F 6$ (E, green) and affinity-purified rabbit anti-M33 $(G$, red). The merge in $F$ shows complete colocalization of Bmil and M33. $(H-J)$ The distribution of the Bmil and Mphl/Rae-28 protein was compared with that of the PML protein. A double-labeling experiment is shown using the $\mathrm{mAb} 5 \mathrm{E} 10$ that recognizes the PML protein $(H$, green) and the rabbit anti-Mph-SM serum ( $J$, red). Although a similar dotted distribution was observed for the PML protein, the merge $(I)$ shows that the staining patterns do not overlap. The two yellow dots in $I$ do not represent real colocalization of PML and Mph, because the confocal images depicted in $H-J$ represent a summation of signals in different focal planes. $(K-M) \mathrm{Mphl} / \mathrm{Rae}-28$ does not colocalize with splicing factors. A double-labeling experiment using monoconal antiserum SC35, recognizing splicing factor (Fu and Maniatis 1990) (K, green) with rabbit anti $\mathrm{Mph}-\mathrm{SM}(M$, red) reveals no colocalization (merge, $L)$.

TAD-Bmil fusion protein gave no blue staining yeast colonies.

The central domain of Bmil is required for anterior skeletal transformation in transgenic mice

Previously, we have shown that E $\mu-B m i l$ transgenic mice that overexpress the Bmil protein by virtue of the immunoglobulin heavy chain enhancer (E $\mu)$, Pim1 promoter and Moloney murine leukemia virus long terminal repeat (LTR) display anterior transformation of the axial skeleton (Alkema et al. 1995). Using the same promoter and enhancer module we generated several independent transgenic mouse lines that highly expressed different mutant forms of the Bmil gene during embryogenesis (Fig. 9; M. Alkema, H. Jacobs, M. van Lohuizen, and A. Berns, in prep.). The E $\mathrm{A}-B m i \Delta P$ and $E \mu-B m i \Delta H$ lines overexpressed carboxy-terminal truncated forms of the Bmil protein lacking the last 87 and 190 amino acids, respectively. The $\mathrm{E} \mu-B m i \Delta Z n$ transgenic lines overexpressed a Bmil mutant protein, in which two highly conserved cysteine residues of the RING finger region are changed to phenylalanine residues. All lines were analyzed for skeletal transformation and compared to the previously reported E $\mu-B m i 1$ transgenic mice. The E $\mu-B m i \Delta H$ transgenic mice did not show skeletal abnormalities. However, both the $E \mu-B m i \Delta P$ and $E \mu-B m i \Delta Z n$ transgenic mice showed transformation of cervical $(C)$, thoracic (T), lumbar (L), and sacral (S) vertebrae (Table 1). Anterior transformation of the $E \mu-B m i \Delta P$ and the E $\mu-$ $B m i \Delta Z n-21$ transgenic mice include thickening of the 
Bmil, a member of a mammalian Polycomb complex
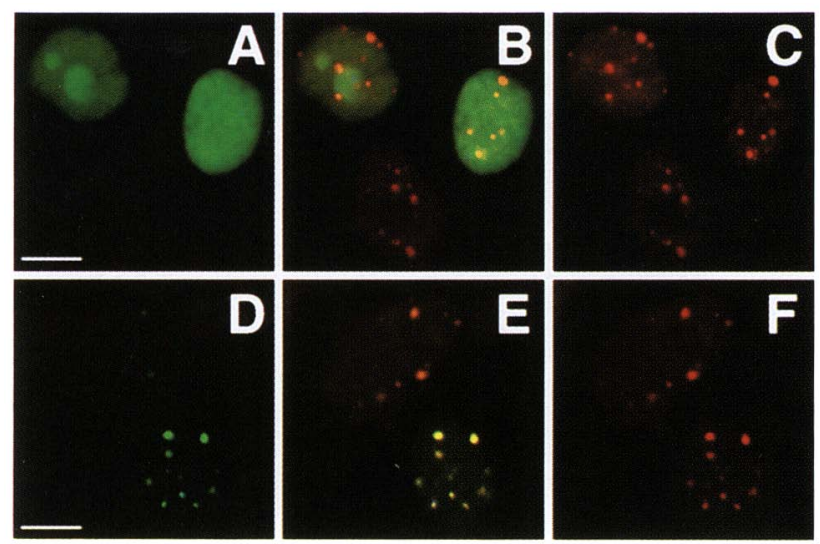

Figure 7. Localization of Bmil to subnuclear domains depends on an intact RING finger. HA-epitope-tagged Bmil $(D-F)$ or HABmil $\Delta$ Zn RING finger mutant $(A-C)$ were transiently transfected into U2-OS cells. HA-tagged proteins were detected 3-4 days after transfection, with indirect immunofluorescence using monoclonal antiserum 12CA5, and compared to endogenous Mphl/Rae-28 (C,F). Wild-type HA-Bmil ( $D$, green) colocalizes with Mphl/Rae-28 (F, red), as indicated by the merge (E). The same frame contains both an untransfected cell (E, top, red) as a transfected cell ( $E$, bottom, yellow), indicating the specificity of the 12CA5 antiserum. In contrast, the RING finger mutant HA-Bmil $1 \Delta \mathrm{Zn}$ displays a diffuse nuclear staining $(A, t o p$, two transfected cells); merge in $B$.

neural arch of $\mathrm{C} 2$, transformation of $\mathrm{T} 1$ toward the identity of $\mathrm{C} 7$ (Fig. 10B,C), transformations of $\mathrm{T} 8$ toward the identity of T7, L1 to T13 and S2 to S1 (Fig. 10F,G; Table 1). In the $E \mu-B m i \Delta Z n-31$ transgenic mice the anterior transformations were restricted to T8 and L6 (Table 1), which could be attributable to a lower expression level of the transgene in these mice (M. Alkema, H. Jacobs, M. van Lohuizen, and A. Berns, in prep.). In contrast to the $E \mu-B m i 1$ transgenic mice, the ribs often were attached asymmetrically to the sternum in the of $\mathrm{E} \mu-B m i \Delta P$ and the E $\mu-B m i \Delta Z n$ transgenic mice (Fig. 10F) or a rib-pair was attached to one side of the sternum but not to the other (Fig. 10G). In general, the shift in segment identity was similar to that observed in the $\mathrm{E} \mu-B m i 1$ transgenic mice, although the penetrance of the anterior transformation in the $\mathrm{E} \mu-B m i \Delta P$ and the $\mathrm{E} \mu-B m i \Delta Z n$ transgenic mice is lower. This could be explained by reduced activity of the mutant Bmil protein or by a lower expression level of the mutant Bmi1 transgene, as the penetrance of the anterior transformations was shown to be Bmil dose dependent. We favor the latter explanation, as in homozygous $\mathrm{E} \mu-B m i \Delta Z n-21$ transgenic mice the penetrance of the anterior transformations was more pronounced than in the heterozygous transgenic littermates and was similar to those observed in $\mathrm{E} \mu-\mathrm{Bmi1}$ homozygous transgenic mice (Table 1; Fig. 10D,H). Our data strongly suggest that overexpression of the central part of the Bmil protein, including the HTHTHT motif, is sufficient for the respecification of vertebrae identity. These data correlate with the domain of the Bmil protein, which was found to be important for the interaction with the Mphl/Rae-28 protein.

\section{Discussion}

Mph1/Rae-28 is a murine homolog of Drosophila ph

We identified Mphl/Rae-28, a murine homolog of the Drosophila Pc-G member ph, in a two-hybrid screen using Bmil and Mell 8 as bait. The Mph/Rae-28 gene was also identified as a RA-inducible cDNA in a mouse embryonal carcinoma cell line (Nomura et al. 1994). Mph1/ Rae-28 shows high similarity to ph in the carboxy-terminal portion of the protein containing a single putative zinc finger and a conserved SEP domain. Other structural similarities between $\mathrm{Mphl} / \mathrm{Rae}-28$ and ph include the overall size of the protein and the presence of glutaminerich regions. Glutamine stretches are also found in other transcriptional regulators, including homeotic proteins. The glutamine-rich region in the transcription factor $\mathrm{Sp} 1$ has been shown to be important for transcriptional activation via interaction with TAF110 (Emami et al. 1995), which is one of the factors associated with the TATAbinding protein (TBP). The glutamine-rich regions in some Pc-G proteins, such as Mph1/Rae-28, might provide a link to the basal transcription apparatus. Interestingly, Bmil expression is induced in the mouse embryo carcinoma cell line P19 upon differentiation by RA (M. van Lohuizen, unpubl.).

Bmi1, Mel18, Mph1/Rae-28, and M33 are constituents of a mammalian Pc complex

Immunoprecipitations of total embryo extracts with Bmil, Mel18, Mph1/Rae-28, or M33 antibodies showed that Bmil and Mell 8 interact with Mph1/Rae-28 in vivo and demonstrate that M33 is also present in the precipitated protein complex. The colocalization of the Bmil, Mph1/Rae-28, and M33 proteins in distinct subnuclear domains in interphase nuclei of U2-OS cells further supports their in vivo interaction. These interactions strongly suggest that the mammalian Pc-G members are constituents of a multimeric protein complex. Other nuclear proteins, associated with distinct functions such as pre-mRNA splicing, RNA transcription (Xing et al. 1993), DNA replication (Newport and Yan 1996), and telomere-associated gene repression (Palladino and Gasser 1994), localize to specific subnuclear domains. We have shown that Bmil, Mph1/Rae-28, and M33 do not colocalize with splicing factors. Other less well-characterized nuclear substructures, which are more reminiscent of the Bmil, Mph1/Rae-28, and M33 distribution, have been described using a variety of human autoimmune antisera (Saunders et al. 1991) and monoclonal antibodies. Some of the autoimmune sera detect proteins in interphase nuclei that colocalize with the RING finger protein PML. Although the size and distribution of the PML-containing subnuclear structures is similar to the ones containing Bmil and Mph1/Rae-28, they do not colocalize. The Drosophila Pc and ph protein show a 
Figure 8. Bmil-Mph1/Rae-28 and Mph1/ Rae-28-Mphl/Rae-28 interaction domains. (A) Schematic representation of Gal4-DBD-Bmil and Gal4-DBD-Mph1/ Rae-28 fusion proteins used to determine the binding domains. The Gal4 DNA-binding domain (amino acids 1-147) and the Gal4 trans-activation domain (amino acids 768-881)-encoding part were fused inframe to the amino terminus of a part of the Bmil or Mph1/Rae-28 protein. The characteristic protein motifs of the Bmil and Mell 8 protein are represented schematically: The shaded box denoted Rnf represents the RING finger domain; the dark-shaded region represents the putative HTHTHT region; $\mathrm{P} / \mathrm{S}$ represents the proline/serine rich region at the carboxyl terminus of the Bmil and Mell 8 protein the small dark-shaded region indicates the nuclear localization signals of the Bmil and Mell 8 protein. The schematically represented protein motifs of the Mph1/Rae28 protein are described in Fig. 3. The amino- and carboxy-terminal amino acids of the protein parts are indicated. The yeast strain Y190 was transformed with the fusion protein-encoding plasmids, and at least 20 colonies were scored for $\beta$-galactosidase activity using a colony lift assay. Specificity of the interaction for combinations of fusion proteins that gave blue staining yeast colonies were confirmed with control Gal4TAD fusion proteins. $(B)$ Summary of the data presented in $A$. The carboxy-terminal 166 amino acids of the $\mathrm{Mph} 1 /$ Rae-28 protein, including the SEP domain, are sufficient for Mph1/Rae-28 dimerization. Amino acids 720-1012 of the Mph1/Rae-28 protein, including the first homology domain, conserved zinc finger, and the SEP domain, are sufficient for Bmil binding. An internal part of the Bmil protein, including the HTHTHT motif, is essential for Mph1/Rae-28 binding.
A
GA14-DBD fusion proteins

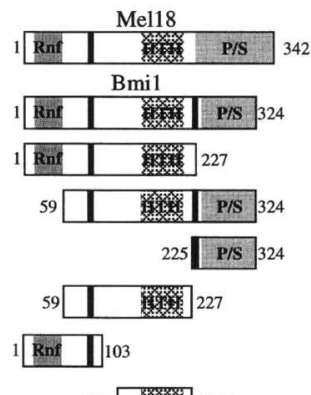

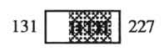

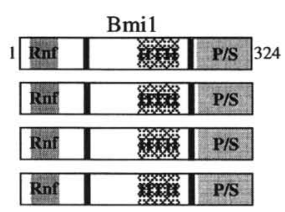

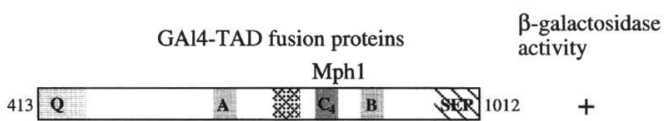

\begin{tabular}{lllllll}
413 & $\mathbf{Q}$ & A & C & B & इसश & $1012+$ \\
\hline
\end{tabular}

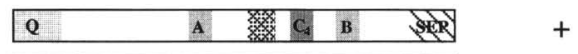

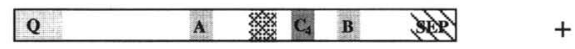

\begin{tabular}{lllllll}
\hline Q & A & C & B & SसP \\
\hline
\end{tabular}

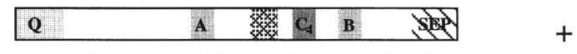

\begin{tabular}{|llllll}
\hline Q & A & C & B & SEP \\
\hline
\end{tabular}

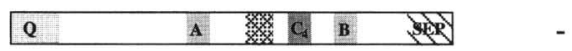

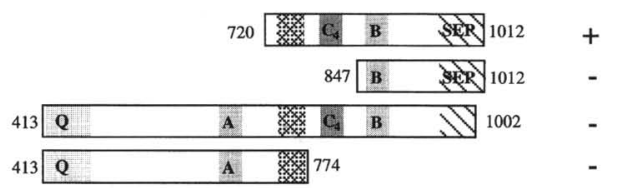

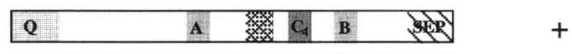
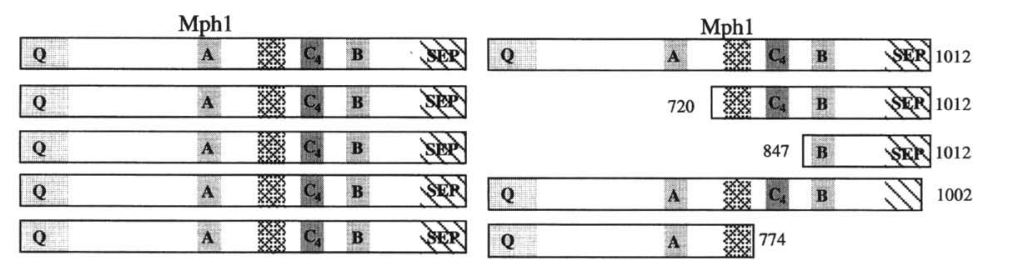

B

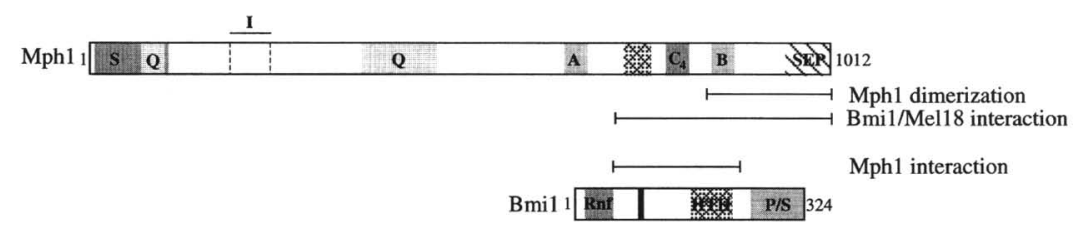

similar speckled distribution in embryonic and tissue culture cells (Messmer et al. 1992; Franke et al. 1995). Interestingly, mutations in the Pc chromodomain affect the subnuclear distribution of the ph protein indicating that the localization of ph depends on Pc function (Franke et al. 1995). Whereas it is tempting to speculate that the speckles seen with Bmil, Mph1/Rae-28, and M33 antisera represent clustered mammalian Pc complexes, it is not yet clear whether the subnuclear domains are functionally important for Pc-G silencing, as a Bmil protein with mutated RING fingers is no longer specifically localized to these domains but still is able to induce anterior transformations of the axial skelton when overproduced in transgenic mice. The transient overproduction of wild-type or RING finger-mutant Bmil in U2-OS cells does not lead to major changes in the distribution of endogenous Bmil or Mph1/Rae-28 proteins, although subtle changes might well have escaped detection at this level of resolution. The lack of drastic changes to the Pc-G protein complex when Bmil is overproduced or deleted are not unexpected, given the subtle posterior or anterior transformations in Bmil knockout or transgenic mice, respectively. In this respect, it will be important in future experiments to analyze the effects on the Pc-G multiprotein complex in Bmil/Mel18 double knockout mice, or EED mutant mice, which show much more severe morphological transformations (Schumacher et al. 1996).

\section{Functional domains of Mph1/Rae-28 and Bmi1}

The carboxy-terminal portion of the Mphl/Rae-28 pro- 
E $\mu B m i$ transgenic lines
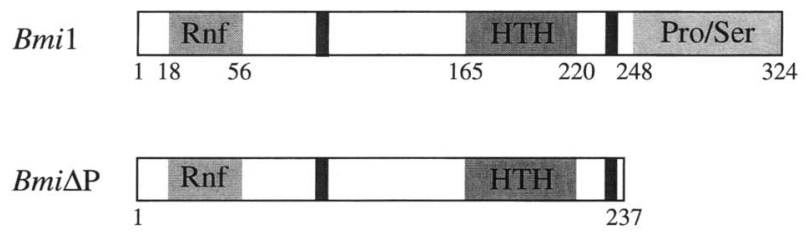

\begin{tabular}{l|l|l|}
\cline { 2 - 2 } Bmi & Rnf & \\
\cline { 2 - 2 } & & \\
\hline 133
\end{tabular}

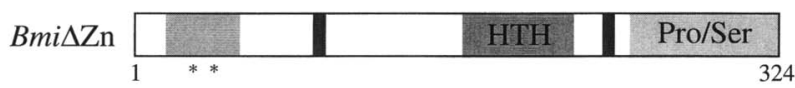

tein with the highest sequence similarity to the ph protein is sufficient for the interaction with the Bmil and Mel18 protein. This part of the protein contains a putative zinc finger and the conserved SEP sequence. Homodimerization of some of the members of the Pc-G might be an important feature in building multimeric protein complexes. Our data provide the first evidence for a functional role of the conserved SEP domain in homodimerization. The presence of a similar sequence in the Pc-G member Scm (Bornemann et al. 1996) suggests that it may also play a role in heterodimerization of ph and Scm. The SEP domain is important for Scm function in flies, as in the $S c m^{X F 24}$ null mutant the carboxyterminal 49 amino acids of the SEP domain are deleted
Skeletal

transformation

Figure 9. The Bmil and mutant Bmi proteins of the different transgenic lines are represented schematically. The amino-terminal RING finger domain (Rnf), the putative HTHTHT (HTH) domain, and the carboxy-terminal proline/serine rich region (Pro/Ser) are shaded. The small dark-shaded regions indicate the nuclear localization signals of Bmil.

(Bornemann et al. 1996). The HLH domain of the c-Myc, MyoD, and E2 class of transcription factors have been shown to be important for homo- and heterodimerization among family members (Murre et al. 1994). Although molecular evidence is currently lacking, a similar role in protein-protein interaction has been suggested for the SEP domain in Ets family members (Wasylyk et al. 1993) and yeast sexual differentiation proteins (Ponting 1995). Mutations in the SEP domain also abolish Bmil binding, suggesting that $\mathrm{Mph} 1 /$ Rae-28 dimerization is required for Bmil binding.

Comparison of the Bmil, Mel18, Psc, Su(z)2 (Brunk et al. 1991; van Lohuizen et al. 1991a), and the recently identified Drosophila lethal(3)73Ah protein (Irminger

Table 1. Abnormalities of the axial skeleton in E $\mu-B m i$ mutant transgenic mice

\begin{tabular}{|c|c|c|c|c|c|c|c|c|}
\hline & & & $\begin{array}{l}\text { wt } \\
\{n=40\}\end{array}$ & $\begin{array}{l}\mathrm{E} \mu-B m i \\
|n=19 / 3|^{*}\end{array}$ & $\begin{array}{l}\mathrm{E} \mu-B m i \Delta P \\
(n=25)\end{array}$ & $\begin{array}{l}\mathrm{E} \mu-B m i \Delta Z N-21 \\
(n=15 / 3)^{\star}\end{array}$ & $\begin{array}{l}E \mu-B m i \Delta Z N-31 \\
(n=10)\end{array}$ & $\begin{array}{l}E \mu-B m i \Delta H \\
|n=9|\end{array}$ \\
\hline $\mathrm{C} 2$ & broadened neural arch & & 0 & $19 / 3^{\star}$ & 3 & 7 & 0 & 0 \\
\hline Ectol & pical aaa & & 0 & 0 & 0 & $0 / 2^{\star}$ & 0 & 0 \\
\hline Assy & metric ribs & & 0 & 0 & 4 & 5 & 4 & 0 \\
\hline \multirow{2}{*}{\multicolumn{2}{|c|}{$\mathrm{Tl}$ sternal rib }} & one side & 0 & 2 & 5 & 1 & 0 & 0 \\
\hline & & both sides & 10 & 0 & 19 & 10 & 10 & 9 \\
\hline \multirow{2}{*}{\multicolumn{2}{|c|}{ rudimentary rib }} & one side & 0 & 9 & 5 & $2 / 1^{\star}$ & 0 & 0 \\
\hline & & both sides & 0 & 9 & 1 & 0 & 0 & 0 \\
\hline \multirow{2}{*}{\multicolumn{2}{|c|}{ no rib }} & one side & 0 & 7 & 1 & $3 / 1^{\star}$ & 0 & 0 \\
\hline & & both sides & 0 & $1 / 3^{\star}$ & 0 & $0 / 2^{*}$ & 0 & 0 \\
\hline \multirow[t]{2}{*}{$\mathrm{T} 2$} & split costal cartilage & one side & 0 & 11 & 4 & $2 / 1^{\star}$ & 0 & 0 \\
\hline & & both sides & 0 & 7 & 0 & 1 & 0 & 0 \\
\hline \multirow[t]{2}{*}{$\mathrm{T} 8$} & ribs attached to sternum & one side & 0 & 0 & 7 & 5 & 2 & 0 \\
\hline & & both sides & 0 & $19 / 3^{\star}$ & 16 & 9 & 4 & 0 \\
\hline \multirow[t]{2}{*}{ L6 } & connected ribs & one side & 0 & 0 & 7 & 3 & 1 & 0 \\
\hline & & both sides & 0 & $19 / 3^{*}$ & 5 & $8 / 3^{\star}$ & 0 & 0 \\
\hline L5 & connected ribs & one side & 0 & 0 & 0 & $0 / 2^{\star}$ & 0 & 0 \\
\hline \multirow[t]{2}{*}{ S2 } & connected to the ilium & one side & 0 & 3 & 10 & $0 / 2^{\star}$ & 0 & 0 \\
\hline & & both sides & 0 & $17 / 2^{\star}$ & 3 & 10 & 0 & 0 \\
\hline S3 & connected to the ilium & one side & 0 & $0 / 1^{\star}$ & 0 & $0 / 2^{\star}$ & 0 & 0 \\
\hline
\end{tabular}

Newborn mice of the different E $\mathrm{H}-\mathrm{Bmi}$ transgenic lines were analyzed for malformations of the axial skeleton under a dissecting microscope. The malformations were compared with those reported previously for mice of the E $\mu-B m i 33$ and E $\mu-b m i 52$ lines (Alkema et al. 1995). Mice that are homozygous for a given genotype are indicated with an asterisk (*). (wt) Wild type. (aaa) anterior arch of the atlas. 
Alkema et al.
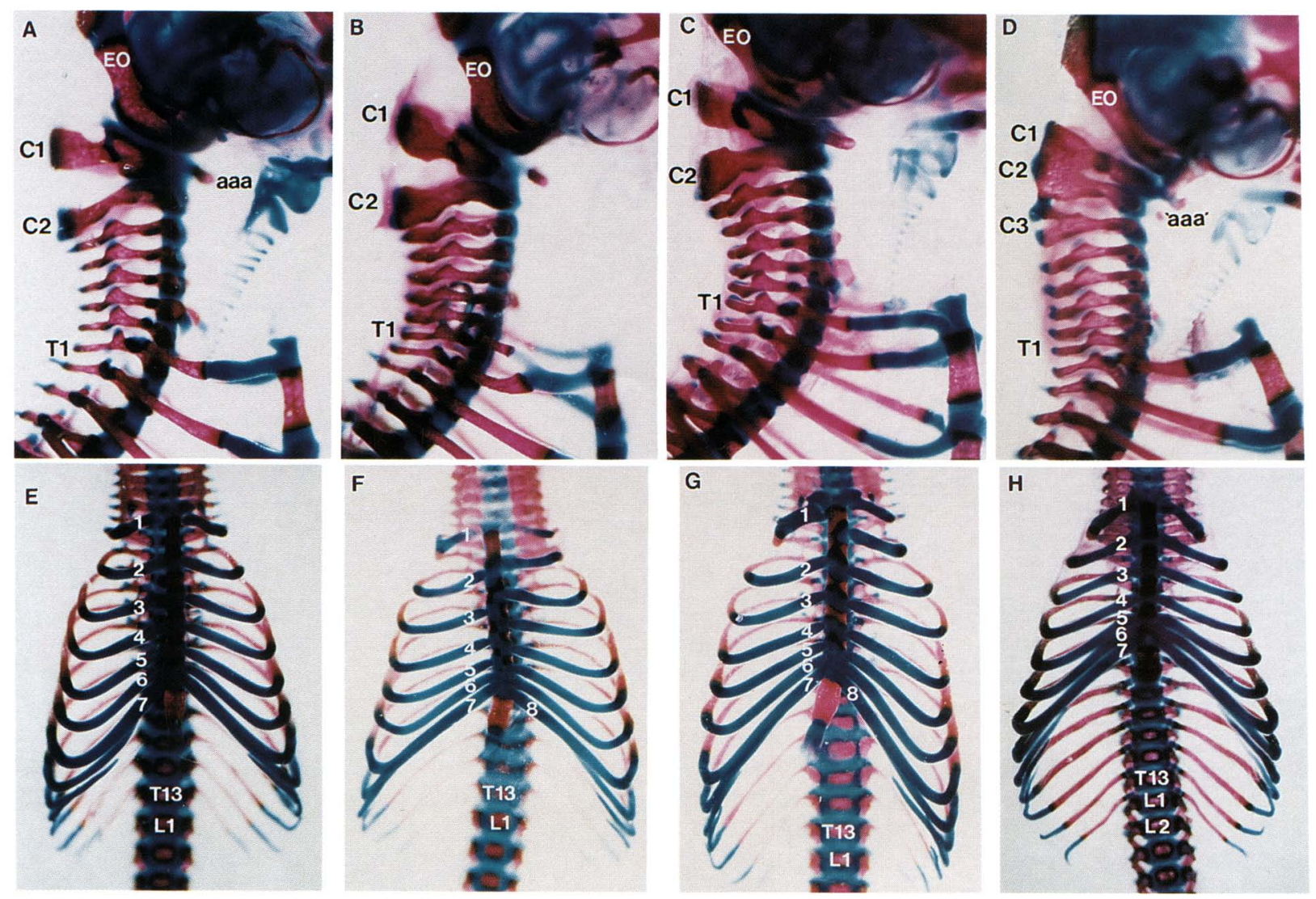

Figure 10. Anterior transformations of the axial skeleton in E $\mu-B m i l$ mutant transgenic mice (see also table 1). Whole-mount alizarin red/alcian blue-stained skeletons of newborn wild-type $(A, E) \mathrm{E \mu}-B m i \Delta P-40(B, F), \mathrm{E \mu}-B m i \Delta Z n-21(C, G)$, and homozygous E $\mu-B m i \Delta Z n$ $21(D, H) .(A-D)$ Lateral view of the occipital, cervical, and upper thoracic region. The exoccipital bone $(\mathrm{EO})$, the atlas $(\mathrm{C} 1)$ with the anterior arch of the atlas (aa), the axis $(\mathrm{C} 2)$, and the first thoracic vertebra (T1) are indicated. The most notable abnormalities in $\mathrm{E} \mu-B m i \Delta P-40$ and $\mathrm{E} \mu-B m i \Delta Z n-21$ transgenic mice included the thickening of the neural arch of the axis $\{\mathrm{C} 2\}$ and transformation of $\mathrm{T} 1$ to the identity of $\mathrm{C} 7(B, C)$. In the $\mathrm{E} \mu-B m i \Delta P-40$ transgenic mouse shown in $B$ a residual rib is present on $\mathrm{T} 1$, which fuses to the costal cartilage of $\mathrm{T} 2$. The $\mathrm{T} 1$ and $\mathrm{T} 2$ ribs of the $\mathrm{E} \mu-B m i \Delta Z n-21$ transgenic mouse shown in $C$ fuse at the sternum. In the transgenic mice shown in $B, C$, and $D$, the dorsal cartilage extension of $\mathrm{T} 2$, the processus spinosus, is now present on T3. The penetrance of the transformation is transgene dosage dependent, as shown in $D$. In homozygous transgenic E $\mu-B m i \Delta Z n 21$ mice T1 is completely transformed to C7, as no residual rib is present anymore. An extra anterior arch is now also present on the ventral side of C2 ('aaa') and the neural arch has broadened further and is fused to the neural arch of $\mathrm{C} 1$. The neural arch of $\mathrm{C} 3$ has also broadened and is split at the dorsal side, which can be interpreted as a transformation to $\mathrm{C} 2 .(E-H)$. Ventral view of thoracic region of a wild-type $(E)$, E $\mu-B m i \Delta P-40\langle F|, E \mu-B m i \Delta Z n-21| G|$ and $E \mu-B m i \Delta Z n-21\langle H\rangle$ homozygous transgenic mouse. The vertebrosternal ribs are numbered. $(F, G)$ The assymetric attachment of the ribs to the sternum often found in these mice. $(F)$ The thorax of an E $\mu-B m i \Delta P-40$ transgenic mouse, in which the sternebrae acquire a zipper-like structure because of an assymetric rib attachment. In $G(\mathrm{E} \mu-B m i \Delta Z n-21)$ there is no rib attached to the sternum opposite to the left rib that originates from T2. Note that ossification occurs at the right side at the attachment site of this rib. In both cases $(F, G)$ eight vertobrosternal ribs are present on the left side, whereas there are the expected seven on the right. $(H)$ In E $\mu-B m i \Delta Z n-21$ homozygous transgenic mice the ribs from $T 8$ are attached to the sternum and a pair of ribs is attached to the first lumbar vertebra (L1).

and Nothiger 1995) revealed two homology regions that may point to domains with functional significance: the RING finger domain at the amino terminus of the Bmil protein and part of the putative HTHTHT domain in the carboxy-terminal half of the protein. The carboxy-terminal part of the Bmil protein contains a region rich in proline, glutamine, and serine residues. Within this region, PEST sequence motifs, implicated in rapid protein degradation, are found. However, they do not seem to confer instability to the Bmil protein in view of the ob- served 10-hr half-life in tissue culture cells (M. van Lohuizen, unpubl.).

Deletion of the RING finger domain and the Pro/Ser rich region did not affect the Bmil-Mph1/Rae-28 interaction indicating that only the internal part of the Bmil protein, including the conserved HTHTHT motif, is important for Mphl/Rae-28 binding. It is relevant to note that overexpression of a Bmil protein lacking the Pro/ Ser rich region or containing mutations in the RING finger domain still induced anterior transformation of 
the skeleton, whereas overexpression of a Bmil protein that lacks the HTHTHT motif did not lead to skeletal transformation. This suggested that the Bmil-Mphl/ Rae-28 interaction is essential for Hox gene regulation. We cannot fully exclude that the Bmil RING finger has a role in Pc-G function, as the mutant Bmil transgenic mice were made in wild-type Bmil background. The RING finger domain is important for other functions of the Bmil protein. In contrast to the $E \mu-B m i 1$ and $E \mu-$ $B m i \Delta P$ transgenic mice the $\mathrm{E} \mu-B m i \Delta Z n$ transgenic mice were no longer predisposed to lymphomagenesis (M. Alkema, H. Jacobs, M. van Lohuizen, and A. Berns, in prep.). In this respect, it is of interest that the RING finger is required for proper subnuclear localization of Bmil. A similar importance for localization to POD domains has been observed for the RING finger of the PML oncoprotein (Borden et al. 1995). Because the RING finger clearly differs from classical DNA-binding zinc fingers in terms of sequence homology and tertiary structure (Barlow et al. 1994; Borden et al. 1995) we think that the Bmil RING finger plays a role in protein-protein rather than protein-DNA interactions. However, it has been reported that the related Mel18 RING finger is essential for DNA binding (Tagawa et al. 1990). Furthermore, it was shown recently that Mell8 binds to a GACTNGACT target DNA sequence using a random oligonucleotide assay (Kanno et al. 1995). Although Bmil has DNA-binding activity (M. Alkema, unpubl.), we have not been able to demonstrate sequence specific binding using a similar assay. Also the related Psc and $\mathrm{Su}(\mathrm{z}) 2$ proteins were reported to have only nonspecific DNA-binding activity (Rastelli et al. 1993).

The posterior transformation of the axial skeleton of the Bmi1 and Mel18 null mutant mice are very much alike, suggesting functional redundancy (van der Lugt et al. 1994; Akasaka et al. 1996). The fact that the Mel18 and Bmil protein share Mphl/Rae-28 as a binding partner supplies a molecular basis for the similar phenotypes in these mice. However, the subset of Hox gene expression boundaries affected in the Mel18 mutant mice only partially overlap with the subset affected by the absence of Bmil. Therefore, multimeric Pc-G protein complexes might be formed in different compositions, each having a different efficacy to repress different subsets of Hox genes.

\section{Materials and methods}

Yeast two-hybrid screen

Yeast strain Y190 (Durfee et al. 1993), which contains two chromosomally located Gal4-inducible reporter genes, HIS3 and lacZ, was transformed with a bait plasmid (pPC97/Chevray and Nathans 1992) containing the entire Bmi1 or Mel18 ORF or part of the Mph1/Rae-28 cDNA (encoding amino acids 4131012) fused to the Gal4 DBD. Production of the Gal4-DBD fusion protein was confirmed with Western blot analysis. The bait-containing strain was subsequently transformed by the lithium acetate method with a pool of plasmids expressing the Gal4 trans-activation domain (TA) fused to random sequences of a 14.5-day CD1 mouse embryo cDNA library (Chevray and
Nathans 1992). One million transformants were selected for growth on plates lacking histidine supplemented with $25 \mathrm{~mm}$ 3 -aminotriazole. $\mathrm{His}^{+}$colonies were subsequently analyzed for $\beta$-galactosidase activity using a colonylift assay. The Bmil screen gave $40 \mathrm{His}^{+}$colonies, 4 of which expressed $\beta$-galactosidase; the Mel18 screen yielded $48 \mathrm{His}^{+}, 3$ of which stained blue after a $\beta$-gal assay; for the Mph1/Rae-28 screen, 10 of 67 colonies that grew on plates lacking histidine also expressed $\beta$-galactosidase. cDNA library plasmids recovered from double-positive yeast colonies were tested for bait specificity by retransformation with different Gal4-DBD fusion plasmids: pPC97-p107, pPC97-BS69, and pPC97 without an insert. To map the interaction domains of Bmil and Mph1/Rae-28, Bmi1 and Mph1/ Rae-28 cDNA fragments were subcloned in the Gal4-DBD and Gal4-TAD vector and cotransformed to Y190. The resulting yeast colonies were then assayed for $\beta$-gal activity.

\section{Immunological reagents}

To generate antibodies against Bmil, Mphl/Rae-28, and Mella GST-Bmil, GST-MphSM, GST-MphMN, and Malc-Mel18 proteins were produced in Escherichia coli and purified with GST-Sepharose or amylose-Sepharose beads, respectively. pGST-Bmi1 was constructed by cloning a cDNA fragment encoding amino acids $1-202$ in pGEX2T (Pharmacia). pGST-MphSM and pGST-MphMN were constructed by cloning a cDNA fragment encoding amino acids $413-760$ (SM) and amino acids $760-$ 1012 (MN) in pGEX2T. pMalc-Mel18 was constructed by cloning a cDNA fragment encoding the entire Me118 ORF in pMalc. The different purified proteins were used to immunize rabbits and mice (pGST-Bmi1). After three rounds of immunization with the different purified fusion proteins polyclonal serum was obtained. The Mph-SM serum was affinity purified using purified Malc-Mphl/Rae-28 protein (amino acids 538-1012) coupled to affigel (Bio-Rad). The polyclonal Bmil serum was affinity purified using $\mathrm{Ni}^{+}$column-purified 6xhis-Bmil (Novagen) fusion protein produced in Sf9 insect cells after infection with a recombinant baculovirus. In vitro transcription/translations followed by immunoprecipitation assay confirmed the specificity of the different polyclonal antibodies. Monoclonal antibodies against pGST-Bmil were made by fusion of splenocytes of immunized BALB/c mice to Sp2O myeloma cells 1 week after the final boost. Positive tissue culture supernatants were identified in an ELISA assay. Supernatants of 12 ELISApositive hybridoma cell lines were tested for immunoprecipitation, Western blotting, and immunofluorescence. M33 antibodies were raised against M33 amino acids 298-519, expressed in E. coli from a PET23 vector (Novagen). For the experiments described in this paper we used the monoclonal antibody F6 against Bmil, and the polyclonal antisera Bmil-38, Mel18-27, MphSM-91, and MphMN-93.

\section{Immunoprecipitations}

Embryo protein extracts were made from 12.5- to 13.5-day murine embryos. Yolk sacs or placentas were used for DNA analysis and subsequent genotyping of the mice as described (Alkema et al. 1995). Embryos were put in $2 \mathrm{ml}$ of Eppendorf tubes in 1 $\mathrm{ml}$ of ELB buffer (Whyte et al. 1988) (containing 5 mM EDTA, $0.5 \mathrm{~mm}$ DTT, $1 \mu \mathrm{g} / \mathrm{ml}$ of chymostatin, aprotinin, antipain, and leupeptin, and $1 \mathrm{~mm}$ phenylmethylsulfonylfluoride) and dounced 10 times with a tight Eppendorf potter, sonicated for 20 $\sec (50 \%$ duty cycle in Branson sonifier), and centrifuged for 15 min in an Eppendorf centrifuge at 14,000 rpm. The supernatant of the lysate was used for immunoprecipitations. The protein concentration of the embryonic extracts was measured by the 
Bradford method. The lysate was precleared for $1 \mathrm{hr}$ with normal mouse or rabbit serum coupled to protein A-Sepharose beads and $250 \mu \mathrm{l}$ of the supernatant (protein concentration 10 $\mathrm{mg} / \mathrm{ml}$ ) was used in immunoprecipitations with $3 \mu \mathrm{l}$ of antiserum or $100 \mu \mathrm{l}$ of tissue culture supernatant from hybridoma cells. After $1 \mathrm{hr}$ at $4^{\circ} \mathrm{C}$ immune complexes were collected with $30 \mu \mathrm{l}$ of protein A-Sepharose and washed four times $(5 \mathrm{~min})$ in $1 \mathrm{ml}$ of ELB buffer and transferred to a fresh tube for a final wash step. After adding $30 \mu \mathrm{l}$ two times sample buffer, the immunoprecipitated proteins were separated on a $9 \%$ SDS-polyacrylamide gel and transferred to nitrocellulose.

\section{Western blot analysis}

Nitrocellulose membrane was blocked in PBST (PBS, $0.05 \%$ Tween 20 ) containing $5 \%$ dried milk for $3 \mathrm{hr}$ at room temperature. The membrane was subsequently incubated with the antibody diluted 1:2000-5000 in PBST containing 1\% dried milk for $1 \mathrm{hr}$ at room temperature. After washing, the membrane was incubated with horseradish peroxidase-linked swine anti-rabbit IgG or goat anti-mouse IgG as second antibody in PBST containing $1 \%$ dried milk for $1 \mathrm{hr}$ at room temperature. Antibodies were detected by enhanced chemiluminescence (Amersham).

\section{Transfection experiments}

COS-7 cells were grown in Dulbecco's modified Eagle medium (DMEM) with $10 \%$ FCS. For transfections, cells were seeded at a density of $2 \times 10^{5}$ per well in six-well culture dishes. The next day cells were incubated with lipofectamine (GIBCO-BRL) containing $2 \mu \mathrm{g}$ of plasmid DNA/well, according to the manufacturers descriptions. After $48 \mathrm{hr}$ total protein extracts were prepared in ELB, as described above.

$\mathrm{U} 2-\mathrm{OS}$ cells were transfected (8 $\mu \mathrm{g}$ of plasmid DNA $+0.5 \mu \mathrm{g}$ of puromycin-selectable marker DNA) using standard $\mathrm{CaPO}_{4}$ precipitation, according to standard procedures. One day after transfection, cells were subjected to puromycin selection $(8 \mathrm{\mu g} /$ $\mathrm{ml}$ ), for $36 \mathrm{hr}$ to kill off $95 \%-99 \%$ of untransfected cells. Remaining cells were seeded on multiwell coverslips, recovered for 1 day without puromycin, and processed for immunofluorescence as described below.

\section{Immunofluorescence}

The cell line U2OS was grown DMEM with $10 \%$ fetal calf serum on multiwell coverslips to $\sim 50 \%$ confluence, washed three times in PBS, and fixed in freshly prepared $2 \%$ formaldehydePBS for $15 \mathrm{~min}$ at room temperature. The cells were incubated subsequently in $2 \times 5$ min with PBS; 5 min with PBS containing $0.5 \%$ Triton X-100; $2 \times 5$ min with PBS; 5 min with $0.1 \mathrm{M}$ glycine in PBS, and $2 \times 5$ min with PBS; preblocked in blocking solution (PBS containing 5\% fetal calf serum, $5 \%$ normal goat serum, $0.02 \%$ Triton $\mathrm{X}-100$ ) for $1 \mathrm{hr}$ at room temperature; $2 \mathrm{hr}$ at room temperature with 1:40 diluted Bmil-F6 monoclonal antibody, 1:100 diluted SC35 monoclonal, 1:40 diluted anti PML 5E10 monoclonal antibody (Stuurman et al. 1992), or 1:20 diluted affinity-purified rabbit polyclonal Mph1/Rae-28 antibody or affinity-purified M33 polyclonal antibody, respectively, in blocking solution; $4 \times 5$ min with PBS $+0.02 \%$ Triton X-100; $1 \mathrm{hr}$ at room temperature with 1:100 diluted FITC-conjugated goat anti-mouse (Jackson Immuno Research Laboratories), or 1:1000 diluted goat anti-rabbit-TRITC in blocking solution. After $4 \times 5$ min with PBS $+0.02 \%$ Triton X-100 specimens were embedded in vectastain (+ or - propidium iodide stain). Images of labeled cells were produced on a Bio-Rad confocal laser scanning microscope with a $63 \times / 1.35$ oil immersion lens. FITC and
TRITC were recorded separately and then superimposed. When first antisera were omitted or replaced with NRS/NMS as specificity controls, no significant background signal was detected.

\section{Northern blot analysis}

RNA from total embryos or adult tissue was isolated by the LiCl-urea method. For Northern blot analysis, $15 \mu \mathrm{g}$ of total RNA or $5 \mu \mathrm{g}$ of poly $(\mathrm{A})^{+}$RNA was separated on a $1 \%$ agarose gel and transferred to nitrocellulose filters. The Bmi1 cDNA fragment encoding the ORF, Mel18 cDNA fragment encoding the ORF, or the longest Mph1/Rae-28 two-hybrid cDNA clone was labeled by the random priming method and used as a probe. Filters were hybridized as described (Sambrook et al. 1989) and washed at $0.1 \times \mathrm{SSC}, 0.1 \% \mathrm{SDS}$, at $65^{\circ} \mathrm{C}$.

\section{cDNA cloning and sequencing}

A partial Mph1/Rae-28 two-hybrid cDNA clone was used as a probe as described (Alkema et al. 1993) to screen a 16.5-day mouse embryo cDNA library. Sequencing was performed on both strands by the dideoxy chain termination method using a Promega T7 polymerase sequencing kit, with 7-deazadGTP to resolve compression in $\mathrm{G} / \mathrm{C}$-rich areas. Initial sequencing was performed using T7, Sp6, and T3 sequence primers. Sequences obtained with these primers were subsequently used to synthesize internal oligonucleotide primers for further sequence analysis.

\section{Skeletal analysis}

Whole-mount skeletons of newborn mice were stained with alcian blue 8GS and alizarin red as described (van der Lugt et al. 1994). DNA was isolated from a tissue sample and analyzed by Southern blot analysis to determine the presence of the transgene as described (Alkema et al. 1995). The samples were cleared for 1 week in $1 \% \mathrm{KOH}$ followed by 1 -week clearing steps in $0.8 \% \mathrm{KOH}, 20 \%$ glycerol, $0.5 \% \mathrm{KOH}, 50 \%$ glycerol. Cleared skeletons were transferred to $50 \%$ glycerol, $50 \%$ ethanol, for photography and storage. Transgenic mice and embryos were identified by Southern blotting of EcoRI-digested tail or extra embryonic tissue DNA, using the Bmil 19.1 probe (Alkema et al. 1995).

\section{Acknowledgments}

We thank $\mathrm{H}$. Brady and N. van der Lugt for critically reading the manuscript, N. Bosnie, L. Rijswijk, and K. Kieboom for assistance in animal care, R. Regnerus for genotyping the mice, R. van Driel for the 5E10 monoclonal antibody, and W. Voncken for the HA-tagged M33 construct. We would like to thank N.G. Copeland for mapping the Mph1/Rae-28 gene, T. Hamersveld and J. Hilkens for their help in generating the antibodies, A Perakis for assistance with the protein alignments, and L. Oomen for expert assistance with the confocal laser microscope. This work was supported by the Netherlands Cancer Society (M.J.A.).

The publication costs of this article were defrayed in part by payment of page charges. This article must therefore be hereby marked "advertisement" in accordance with 18 USC section 1734 solely to indicate this fact.

\section{Note}

The Mphl sequence has been deposited to the GenBank data library under accession no. U63386. 


\section{References}

Akasaka, T., M. Kanno, R. Balling, M.A. Miesa, M. Taniguchi, and H. Koseki. 1996. A role for mel-18, a Polycomb group related vertebrate gene, during the anteroposterior specification of the axial skeleton. Development 122: 1513-1522.

Alkema, M.J., J. Wiegant, A.K. Raap, A. Berns, and M. van Lohuizen. 1993. Characterization and chromosomal localization of the human proto- oncogene BMI-1. Hum. Mol. Genet. 2: 1597-1603.

Alkema, M.J., N.M. van der Lugt, R.C. Bobeldijk, A. Berns, and M. van Lohuizen. 1995. Transformation of axial skeleton due to overexpression of Bmi-1 in transgenic mice. Nature 374: 724-727.

Barlow, P.N., B. Luisi, A. Milner, M. Elliott, and R. Everett. 1994. Structure of the C3HC4 domain by $1 \mathrm{H}$-nuclear magnetic resonance spectroscopy. A new structural class of zincfinger. J. Mol. Biol 237: 201-211.

Bienz, M. and J. Müller. 1995. Transcriptional silencing of homeotic genes in Drosophila. BioEssays 17: 775-784.

Borden, K.L., M.N. Boddy, J. Lally, N.J. O'Reilly, S. Martin, K. Howe, E. Solomon, and P.S. Freemont. 1995. The solution structure of the RING finger domain from the acute promyelocytic leukaemia proto-oncoprotein PML. EMBO $I$. 14: $1532-1541$.

Bornemann, D., E. Miller, and J. Simon. 1996. The Drosphila Polycomb group gene Sex combs on midleg ( $\mathrm{Scm}$ ) encodes a zinc finger protein with similarity to polyhomeotic protein. Development 122: 1621-1630.

Brunk, B.P., E.C. Martin, and P.N. Adler. 1991. Drosophila genes Posterior Sex Combs and Suppressor two of zeste encode proteins with homology to the murine Bmi-1 oncogene. Nature 353: 351-353.

Busturia, A. and M. Bienz. 1993. Silencers in abdominal-B, a homeotic Drosophila gene. EMBO J. 12: 1415-1425.

Chan, C.S., L. Rastelli, and V. Pirrotta. 1994. A Polycomb response element in the Ubx gene that determines an epigenetically inherited state of repression. EMBO J. 13: 25532564.

Cheng, N.N., D.A. Sinclair, R.B. Campbell, and H.W. Brock. 1994. Interactions of polyhomeotic with Polycomb group genes of Drosophila melanogaster. Genetics 138:1151-1162.

Chevray, P.M. and D. Nathans. 1992. Protein interaction cloning in yeast: Identification of mammalian proteins that react with the leucine zipper of Jun. Proc. Natl. Acad. Sci. 89: 5789-5793.

Chiang, A., M.B. O'Connor, R. Paro, J. Simon, and W. Bender. 1995. Discrete Polycomb-binding sites in each parasegmental domain of the bithorax complex. Development 121: 1681-1689.

Chien, C.T., P.L. Bartel, R. Sternglanz, and S. Fields. 1991. The two-hybrid system: A method to identify and clone genes for proteins that interact with a protein of interest. Proc. Natl. Acad. Sci. 88: 9578-9582.

Deatrick, J., M. Daly, N.B. Randsholt, and H.W. Brock. 1991. The complex genetic locus polyhomeotic in Drosophila melanogaster potentially encodes two homologous zinc-finger proteins. Gene 105: 185-195.

DeCamillis, M., N.S. Cheng, D. Pierre, and H.W. Brock. 1992. The polyhomeotic gene of Drosophila encodes a chromatin protein that shares polytene chromosome-binding sites with Polycomb. Genes \& Dev. 6: 223-232.

Durfee, T., K. Becherer, P.L. Chen, S.H. Yeh, Y. Yang, A.E. Kilburn, W.H. Lee, and S.J. Elledge. 1993. The retinoblastoma protein associates with the protein phosphatase type 1 catalytic subunit. Genes \& Dev. 7: 555-569.
Dyck, J.A., G.G. Maul, W.H. Miller, Jr., J.D. Chen, A. Kakikuza, and R.M. Evans. 1994. A novel macromolecular structure is a target of the promyelocyte-retinoic acid receptor oncoprotein. Cell 76: 333-343.

Emami, K.H., W.W. Navarre, and S.T. Smale. 1995. Core promoter specificities of the Spl and VP16 transcriptional activation domains. Mol. Cell. Biol. 15: 5906-5916.

Franke, A., S. Messmer, and R. Paro. 1995. Mapping functional domains of the polycomb protein of Drosophila melanogaster. Chromosome Res. 3: 351-360.

Franke, A., M. DeCamillis, D. Zink, N. Cheng, H.W. Brock, and R. Paro. 1992. Polycomb and polyhomeotic are constituents of a multimeric protein complex in chromatin of Drosophila melanogaster. EMBO I. 11: 2941-2950.

$\mathrm{Fu}$, X.D. and T. Maniatis. 1990. Factor required for mammalian spliceosome assembly is localized to discrete regions in the nucleus. Nature 343: 437-441.

Haupt, Y., W.S. Alexander, G. Barri, S.P. Klinken, and J.M. Ad ams. 1991. Novel zinc finger gene implicated as myc collaborator by retrovirally accelerated lymphomagenesis in

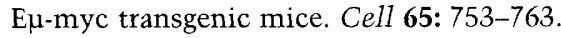

Irminger, F.I. and R. Nothiger. 1995. The Drosophila melanogaster gene lethal(3)73Ah encodes a RING finger protein homologous to the oncoproteins MEL18 and BMI-1. Gene 163: 203-208.

Jürgens, G. 1985. A group of genes controlling the spatial expression of the bithorax complex in Drosophila. Nature 316: 153-155.

Kanno, M., M. Hasegawa, A. Ishida, K. Isono, and M. Taniguchi. 1995. Mel18, a Polycomb group-related mammalian gene, encodes a transcriptional negative regulator with tumor suppressive activity. EMBO J. 14: 5672-5678.

Kastner, P., A. Perez, Y. Lutz, C. Rochette-Egly, M.P. Gaub, B. Durand, M. Lanotte, R. Berger, and P. Chambon. 1992. Structure, localization and transcriptional properties of two classes of retinoic acid receptor alpha fusion proteins in acute promyelocytic leukemia (APL): structural similarities with a new family of oncoproteins. EMBO J. 11: 629-642.

Kennison, J.A. 1993. Trascriptional activation of Drosophila homeotic genes from distant regulator elements. Trends Genet. 9: 75-79.

Krumlauf, R. 1994. Hox genes in vertebrate development. Cell 78: 191-201.

Lonie, A., R. D'Andrea, R. Paro, and R. Saint. 1994. Molecular characterization of the Polycomblike gene of Drosophila melanogaster, a trans-acting negative regulator of homeotic gene expression. Development 120: 2629-2636.

Messmer, S., A. Franke, and R. Paro. 1992. Analysis of the functional role of the Polycomb chromo domain in Drosophila melanogaster. Genes \& Dev. 6: 1241-1254.

Müller, J. 1995. Transcriptional silencing by the Polycomb protein in Drosophila embryos. EMBO I. 14: 2056-2065.

Müller, J. and M. Bienz. 1991. Long range repression conferring boundaries of Ultrabithorax expression in the Drosophila embryo. EMBO 7. 10: 3147-3155.

Müller, J., S. Gaunt, and P.A. Lawrence. 1995. Function of the Polycomb protein is conserved in mice and flies. Development 121: 2847-2852.

Murre, C., G. Bain, M.A. van Dijk, I. Engel, B.A. Furnari, M.E. Massari, J.R. Matthews, M.W. Quong, R.R. Rivera, and M.H. Stuiver. 1994. Structure and function of helix-loop-helix proteins. Biochem. Biophys. Acta. 1218: 129-135.

Newport, J. and H. Yan. 1996. Organization of DNA into foci during replication. Curr. Opin. Cell. Biol. 8: 365-368.

Nomura, M., Y. Takihara, and K. Shimada. 1994. Isolation and characterization of RA-inducible cDNA clones in F9 cells: 
One of the early inducible clones encodes a novel protein sharing several highly homologous regions with a Drosophila polyhomeotic protein. Differentiation 57: 39-50.

Palladino, F. and S.M. Gasser. 1994. Telomere maintenance and gene repression: a common end? Curr. Opin. Cell. Biol. 6: $373-379$.

Paro, R. 1993. Mechanisms of heritable gene repression during development of Drosophila. Curr. Opin. Cell Biol. 5: 9991005.

Pearce, J.J., P.B. Singh, and S.J. Gaunt. 1992. The mouse has a Polycomb-like chromobox gene. Development 114:921929.

Pirrotta, V. 1995. Chromatin complexes regulating gene expression in Drosophila. Curr. Opin. Genet. Dev. 5: 466-472.

Platero, J.S., T. Hartnett, and J.C. Eissenberg. 1995. Functional analysis of the chromo domain of HP1. EMBO J. 14: 3977 . 3986.

Ponting, C.P. 1995. SAM: A novel motif in yeast sterile and Drosophila polyhomeotic proteins. Protein Sci. 4: 19281930.

Rastelli, L., C.S. Chan, and V. Pirrotta. 1993. Related chromosome binding sites for zeste, suppressors of zeste and Polycomb group proteins in Drosophila and their dependence on Enhancer of zeste function. EMBO T. 12: 1513-1522.

Rost, B. 1996. PHD: predicting one-dimensional protein structure by profile-based neural networks. Methods Enzymol. 266: 525-539.

Rost, B. and C. Sander. 1994. Structure predictions of proteinswhere are we now? Curr. Op. Biotechnology 5: 378-380.

Sambrook, J., E.F. Fritsch, and T. Maniatis. 1989. Molecular cloning: A laboratory manual. Cold Spring Harbor Laboratory Press, Cold Spring Harbor, NY.

Saunders, W.S., C.A. Cooke, and W.C. Earnshaw. 1991. Compartmentalization within the nucleus: Discovery of a novel subnuclear region. I. Cell Biol. 115: 919-931.

Schumacher, A., C. Faust, and T. Magnuson. 1996. Positional cloning of a global regulator of anterior-posterior patterning in mice. Nature 383: 250-253.

Simon, J., A. Chiang, W. Bender, M.J. Shimell, and M. O'Connor. 1993. Elements of the Drosophila Bithorax complex that mediate repression by Polycomb group products. Genes \& Dev. 7: 1508-1520.

Stuurman, N., A. de Graaf, A. Floore, A. Josso, B. Humbel, L. de Jong, and R. van Driel. 1992. A monoclonal antibody recognizing nuclear matrix-associated nuclear bodies. J. Cell Sci. 101: 773-784.

Tagawa, M., T. Sakamoto, K. Shigemoto, H. Matsubara, Y. Tamura, T. Ito, I. Nakamura, A. Okitsu, K. Imai, and M. Taniguchi. 1990. Expression of novel DNA-binding protein with zinc finger structure in various tumor cells. J. Biol. Chem. 265: 20021-20026.

Thompson, J.D., D.G. Higgins, and T.J. Gibson. 1994 CLUSTAL W: Improving the sensitivity of progressive multiple sequence alignment through sequence weighting, position-specific gap penalties and weight matrix choice. Nucleic Acid Res. 22: 4673-4680.

van der Lugt, N.M.T., J. Domen, K. Linders, M. van Roon, E. Robanus Maandag, $H$. te Riele, M. van der Valk, J. Deschamps, M. Sofroniew, M. van Lohuizen, and A. Berns. 1994. Posterior transformation, neurological abnormalities, and severe hematopoietic defects in mice with a targeted deletion of the bmi-1 proto-oncogene. Genes \& Dev. 8: $757-$ 769.

van der Lugt, N.M.T., M.J. Alkema, A. Berns, and J. Deschamps. 1996. The Polycomb-group homolog Bmi-1 is a regulator of murine Hox gene expression. Mech. Dev. 58: 153-164. van Lohuizen, M., Frasch, M., E. Wientjens, and A. Berns. 1991a Sequence similarity between the mammalian $B m i-1$ protooncogene and the Drosophila regulatory genes Psc and Sulz|2. Nature 353: 353-355.

van Lohuizen, M., S. Verbeek, B. Scheijen, E. Wientjens, H. van der Gulden, and A. Berns. 199lb. Identification of cooperating oncogenes in E $\mu-m y c$ transgenic mice by provirus tagging. Cell 65: 737-752.

Wasylyk, B., S.L. Hahn, and A. Giovane. 1993. The Ets family of transcription factors. Eur. J. Biochem. 211: 7-18.

Weis, K., S. Rambaud, C. Lavau, J. Jansen, T. Carvalho, F.M. Carmo, A. Lamond, and A. Dejean. 1994. Retinoic acid regulates aberrant nuclear localization of PML-RAR alpha in acute promyelocytic leukemia cells. Cell 76: 345-356.

Whyte, P., K.J. Buchkovich, J.M. Horowitz, S.H. Friend, M. Raybuck, R.A. Weinberg, and E. Harlow. 1988. Association between an oncogene and an anti-oncogene: The adenovirus E1A proteins bind to the retinoblastoma gene product. $\mathrm{Na}$ ture 334: 124-129.

Wismar, J., T. Loffer, N. Habtemichel, O. Vef, M. Geissen, R. Zirwes, W. Altmeyer, H. Sass, and E. Gateff. 1995. The Drosophila melanogaster tumor suppressor gene lethal(3)malignant brain tumor encodes a proline-rich protein with a novel zinc finger. Mech. Dev. 53: 141-154.

Xing, Y., C.V. Johnson, P.R. Dobner, and J.B. Lawrence. 1993. Higher level organization of individual gene transcription and RNA splicing (see Comments). Science 259: 1326-1330.

Yu, B.D., J.L. Hess, S.E. Horning, G.A. Brown, and S.J. Korsmeyer. 1995. Altered Hox expression and segmental identity in Mll-mutant mice. Nature 378: 505-508.

Zhang, C.C. and M. Bienz. 1992. Segmental determination in Drosophila conferred by hunchback (hb), a repressor of the homeotic gene Ultrabithorax (Ubx). Proc. Natl. Acad. Sci. 89: 7511-7515. 


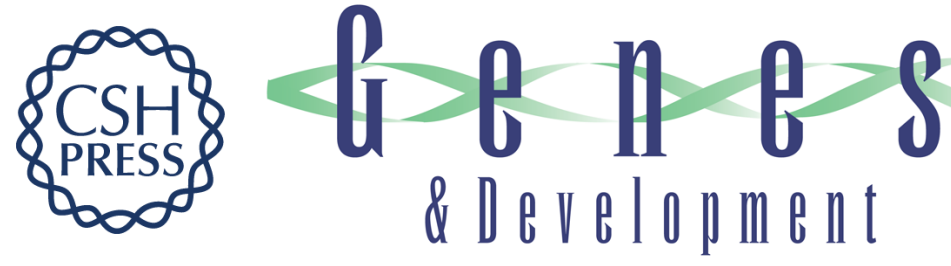

\section{Identification of Bmi1-interacting proteins as constituents of a multimeric mammalian polycomb complex.}

M J Alkema, M Bronk, E Verhoeven, et al.

Genes Dev. 1997, 11:

Access the most recent version at doi:10.1101/gad.11.2.226

References This article cites 63 articles, 20 of which can be accessed free at:

http://genesdev.cshlp.org/content/11/2/226.full.html\#ref-list-1

License

Email Alerting

Service

Receive free email alerts when new articles cite this article - sign up in the box at the top right corner of the article or click here.

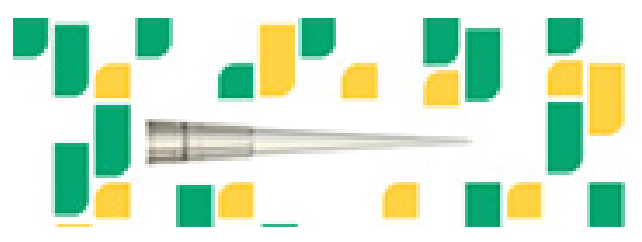

Focused on your science. 